\title{
Genetic tools and techniques for Chlamydomonas reinhardtii
}

Jan H. Mussgnug

Bielefeld University, Faculty of Biology, Center for Biotechnology (CeBiTec), Universitätsstrasse 27, 33615, Bielefeld, Germany.

Address correspondence to: Jan H. Mussgnug, jan.mussgnug@uni-bielefeld.de

Present/Permanent address: Bielefeld University, Faculty of Biology, Center for Biotechnology (CeBiTec), Universitaetsstrasse 27, 33615 Bielefeld, Germany. Phone: +49 521 106-12260, Fax: +49 521 106-12290

\begin{abstract}
The development of tools has always been a major driving force for the advancement of science. Optical microscopes were the first instruments that allowed discovery and descriptive studies of the subcellular features of microorganisms. Although optical and electron microscopes remained at the forefront of microbiological research tools since their inventions, the advent of molecular genetics brought about questions which had to be addressed with new "genetic tools". The unicellular green microalgal genus Chlamydomonas, especially the most prominent species $C$. reinhardtii, has become a frequently used model organism for many diverse fields of research and molecular genetic analyses of $C$. reinhardtii, as well as the available genetic tools and techniques, have become increasingly sophisticated throughout the last decades.

The aim of this review is to provide an overview of the molecular key features of $C$. reinhardtii and summarize the progress related to the development of tools and techniques for genetic engineering of this organism, from pioneering DNA transformation experiments to state-of-the-art techniques for targeted nuclear genome editing and high-throughput screening approaches.
\end{abstract}

\section{Keywords}

Chlamydomonas reinhardtii, genetic engineering, gene silencing, molecular toolkit, promoters, selectable markers 


\section{Introduction}

Genetic tool development for $C$. reinhardtii has been a prospering field of research for more than 30 years and relevant review articles have been published periodically. The Chlamydomonas Sourcebook represents the most extensive collection of information on the organism with the most recent edition having been published in 2009 (Harris 2009). Although only few genetic tools are established for $C$. reinhardtii which would qualify as being "ready-to-use" without significant adaptation, a great number of individual tool elements, techniques and strategies have been published which can be applied separately, or in combination, to accomplish a specific genetic engineering task.

With this review article it is my intention to provide a comprehensive overview of the progress of genetic tool and technique development for $C$. reinhardtii, with a particular focus on options for transgene expression and techniques for endogenous gene expression inhibition. The historical context and important features of the organism are introduced briefly before important practical aspects for selection of appropriate engineering strategies are addressed, including tool delivery options, cell line characteristics, genetic elements for transgene expression, transformant selection and options for gene expression inhibition in chloroplast and nucleus.

Since promoters and transformation markers are important elements for virtually all genetic tools, an extended overview of the current options is provided as Supplementary Material for this article.

\section{Historical background, general features and motivation to use $C$. reinhardtii as a research object}

The invention of optical microscopes and their propagation by natural scientist like Robert Hooke and Antoni van Leeuwenhoek in the $17^{\text {th }}$ century made it for the first time possible to gain insight into the morphology and physiology of microorganisms. Systematic investigations on aquatic microalgae belonging to the genus Chlamydomonas began in the early $19^{\text {th }}$ century. In a series of lectures at the academy of sciences in Berlin between 1828 and 1835, C. G. Ehrenberg described and classified numerous microorganisms and in his third contribution in 1832, he introduced the novel genus Chlamydomonas (spelled Chlamidomonas in the respective article subsequently published (Ehrenberg 1834)). Since the first description of this new genus, scientific research with Chlamydomonas species has grown continuously because this photosynthetic green microalga represents an outstanding model organism for many physiological and genetic studies (Harris 2001). Chlamydomonas species are globally distributed and have been isolated from highly diverse habitats, ranging from polar to tropical climate zones and from soil to fresh or marine water (Harris 2009). C. reinhardtii is the best investigated microalgal species today and, as has been pointed out before (Merchant et al. 2007), represents a common ancestor of animals and plants. Therefore besides studying specific cellular features, key functions related to various distant research fields can be addressed with this species as a model organism. C. reinhardtii is a eukaryotic unicellular photosynthetic green microalga (order Volvocales, family Chlamydomonadaceae, see (Pröschold et al. 2001) for a detailed phylogenic description of the genus). Besides the typical eukaryotic compartmentation, wild type (wt) C. reinhardtii cells feature two apical flagella (anchored in basal bodies), a chloroplast, a pyrenoid, an eye-spot and are surrounded by a cell wall mainly composed of hydroxyproline-rich glycoproteins (Harris 2009). The mitochondrial, chloroplast and nuclear genomes have been fully sequenced, annotated and can be accessed via public databases (Blaby et al. 2014). The nuclear genome of vegetative cells is haploid and two mating types (plus and minus) are described, allowing sexual and asexual cell propagation. Axenic cultivation in the laboratory is simple and can be carried out from strict photolithoautotrophic (light, $\mathrm{H}_{2} \mathrm{O}, \mathrm{CO}_{2}$ ) to strict chemoorganoheterotrophic (dark, acetate as the organic carbon source) conditions. Fast 
vegetative growth rates with generation times of less than seven hours are common (Sager and Granick 1953), allowing fast generation of biomass.

Because of these reasons, a continuously growing number of researches have joined the "Chlamy community" to study such diverse research topics as (see citations for respective topical reviews) photosynthesis \& light acclimation (Allahverdiyeva et al. 2014; Heinnickel and Grossman 2013; Minagawa 2011; Rochaix et al. 2012), respiration (Salinas et al. 2014), flagella \& basal bodies organization and function (Dutcher 2014), life cycle and mating (Umen 2011), carbon metabolism (Johnson and Alric 2013), nutrient membrane transport (Blaby-Haas and Merchant 2012; Grossman 2000), circadian clock (Matsuo and Ishiura 2011; Schulze et al. 2010), photoreceptors (Kianianmomeni and Hallmann 2014), photosynthetic hydrogen (Grossman et al. 2011; Hemschemeier and Happe 2011; Melis et al. 2007) and high and low value compound production (Merchant et al. 2012; Rasala and Mayfield 2015; Rosales-Mendoza et al. 2012; Skjanes et al. 2013), and many more.

\section{Genetic key features of $C$. reinhardtii}

The genetic information of $C$. reinhardtii is compartmentalized into three types of organelles, mitochondria, chloroplast and nucleus. The three genomes differ significantly with respect to genome size, $\mathrm{G}+\mathrm{C}$ content, gene number, DNA organization and copy number per cell. An exclusive advantage of $C$. reinhardtii is that DNA transformation is possible for all three genomes.

\section{The mitochondrial genome}

The size of the mitochondrial genome is $\sim 15.8 \mathrm{~kb}$ (Vahrenholz et al. 1993) with a G+C content of $\sim 45 \%$, it encodes only 13 genes with no introns (Cardol and Remacle 2009). Early electron microscopic evidence indicated that ca. 99\% of the mitochondrial DNA (mtDNA) molecules are linear and only up to $1 \%$ are circular (Ryan et al. 1978) and a recent work indicates that also these circular molecules can act as templates for transcription (Wobbe and Nixon 2013). It is clear that multiple copies of the mtDNA are present per cell, but the exact number is not certain. It was estimated that $46 \mathrm{mtDNA}$ copies are present per cell from early biochemical analyses (Ryan et al. 1978). However work based on fluorochrome staining indicated that the mtDNA is organized as 30-40 small $(\sim 0.1 \mu \mathrm{m})$ nucleoids per vegetative cell (Hiramatsu et al. 2006) and it was estimated that each $0.1 \mu \mathrm{m}$ nucleoid contains around 15 mitochondrial genome copies (Nishimura et al. 1998), which would represent a far higher copy number (450-600) per cell. Most recent evidence suggests that after mating, transmission of the mitochondrial DNA is uniparental by the mating type minus parent (see chapter 7 in Harris 2009), although conflicting data was reported before (Nishimura et al. 1998).

\section{The chloroplast genome}

One chloroplast is present per cell, the size of the circular chloroplast genome is $\sim 203.8 \mathrm{~kb}$ with a $\mathrm{G}+\mathrm{C}$ content of $\sim 35 \%$, encoding 99 genes with five genes containing introns (Higgs 2009; Maul et al. 2002). Typically $\sim 80-90$ chloroplast genome copies, organized in $\sim 10-20$ nucleoids of $<0.2 \mu \mathrm{m}$ in diameter (Harris 2009; Hiramatsu et al. 2006), are present per vegetative cell. The chloroplast DNA molecules seem to exist in multiple circular and linear conformations in vivo (Maul et al. 2002) and sexual transmission is uniparental from the mating type plus parent (see chapter 7 in Harris 2009).

The nuclear genome 
By far the greatest extent of genetic information is stored in the nucleus. According to the most recent annotation, the haploid nuclear genome of $\sim 111.1 \mathrm{Mb}$ is arranged in 17 linkage groups with a $\mathrm{G}+\mathrm{C}$ content of $\sim 64 \%$ (Merchant et al. 2007) and around 19,500 protein-coding transcripts (including splice variants) are being predicted (Joint Genome Institute 2015). Since the nuclear genome is haploid in vegetative cells, recessive mutations do not occur and selection for mutations of specific genes can be straight forward. As mentioned before, the genomes of chloroplast and mitochondria are present in multiple copies per cell and heteroplasmy therefore can here be an issue (Remacle et al. 2006), however, isolation of homoplasmic cell lines is possible (Larosa et al. 2012).

\section{Classical genetic techniques}

Although molecular genetic tools and techniques are in the focus of this review, it is important to note that classical genetic techniques are well established for $C$. reinhardtii. Methods to induce gametogenesis, mating and tetrad analysis have been worked out many years ago and can be performed efficiently in the lab, although not every cell line mates equally well (Harris 2009).

Gametogenesis usually is induced by nitrogen deprivation (Sager and Granick 1954) and mating takes place when plus and minus gametes are mixed. Mediated by agglutinin glycoproteins, flagella of opposite mating type gametes adhere, cell wall lysis and cell fusion occurs and zygospore formation takes place. After a minimum of 2-3 (recommended are 4-6) days of zygospore maturation, germination of the diploid zygotes can be induced by transfer into fresh medium and illumination. After two meiotic divisions, four haploid tetrad cells arise within the zygospore wall. Tetrad cells can then be analyzed individually (see chapter 8 in Harris 2009 for a detailed protocol). Interestingly, occasionally zygotes undergo mitosis, instead of meiosis, resulting in stable vegetative diploid Chlamydomonas strains (Ebersold 1967; Shimogawara et al. 1999). Mating and tetrad analyses have been very important techniques in the past and will continue to be so in the future, e.g. in the context of forward genetics, where the number of unwanted random mutations can be reduced by crossing the mutant with the respective wt.

\section{Molecular genetic tools and techniques}

The first successful DNA transformation of $C$. reinhardtii was achieved by Rochaix \& van Dillewijn more than 30 years ago (Rochaix and van Dillewijn 1982) and since then, many genetic tools and techniques have been developed. Due this progress, multiple strategies and/or tools are in some cases applicable to accomplish a certain engineering task. As an example, production of a given chemical compound within the chloroplast could be achieved via expression of a specific gene from the chloroplast genome, expression from the nucleus (and potentially directing the protein into the chloroplast via targeting signals), or application of a knockdown/knockout strategy to attenuate respective antagonistic pathways. Three aspects are of essential importance for selection of an appropriate genetic engineering strategy: (1) tool delivery; (2) the cell line; (3) the target effect of tool application. The currently available options regarding all three aspects will be addressed in detail in the following chapters.

\section{(1) Techniques for genetic tool delivery}

Genetic tools are macromolecules which must be introduced into the cell to unfold their effects, implicating that several protective layers (cell wall and one or more lipid bilayer membranes) have to be crossed without 
deactivating the tool or irreversibly damaging the cell. Most often, DNA transformation is applied for tool delivery and three strategies are commonly used for $C$. reinhardtii to achieve this goal.

\section{Application of mechanical force by biolistic particle bombardment}

The first stable and highly efficient transformation of $C$. reinhardtii cells was reported in 1988 by restoring chloroplast atpB mutants via biolistic particle bombardment with appropriate DNA-coated tungsten microparticles (Boynton et al. 1988). Since then, gene gun DNA delivery was also applied successfully to transform the nuclear (Day et al. 1990; Debuchy et al. 1989; Kindle et al. 1989) and the mitochondrial (Randolph-Anderson et al. 1993; Remacle et al. 2006; Yamasaki et al. 2005) genomes. Homologous DNA recombination readily occurs in chloroplasts and mitochondria (Boynton et al. 1988; Larosa et al. 2012), however, DNA integration into the nuclear genome occurs preferably at apparently random loci. An early study reported a ratio of homologous vs. nonhomologous integration events of 1:24 after biolistic nuclear transformation (Sodeinde and Kindle 1993), however, this number could even be overestimating the homologous events (Zorin et al. 2005). The presence of a cell wall does not prevent biolistic transformation and since stable transformation of all three genomes is possible, particle bombardment can be regarded as the most versatile of the three delivery options. On the downside, the transformation protocols and the necessary equipment are quite sophisticated compared to the alternative methods.

\section{Application of mechanical force by vortexing}

This method to induce uptake and stable integration of exogenous DNA into the nuclear genome of $C$. reinhardtii was introduced shortly after establishment of the biolistic transformation and is based on simple vortexing of algal cell suspension in the presence of exogenous DNA and microparticles, e.g. glass beads (Kindle 1990) or silicon carbide whiskers (Dunahay 1993). Only little and cheap equipment is necessary to perform DNA transformation with this method and because of this advantage, the procedure is commonly applied for nuclear transformation. A disadvantage of the vortexing method is that the outer cell wall inhibits DNA uptake, therefore it can only be applied efficiently after autolysin treatment or with cell wall deficient strains (Kindle 1990). As described for biolistics, vortexing promotes random integration of the exogenous DNA into the nuclear DNA with a frequency of homologous vs. nonhomologous events of 1:1000 (Sodeinde and Kindle 1993) or even less (Gumpel et al. 1994; Nelson and Lefebvre 1995). Zorin et al. introduced a method based on the use of single-stranded, instead of double-stranded, DNA and showed a significant increase of the relative frequency of site-directed integration events (Zorin et al. 2005; Zorin et al. 2009). However, isolation of specific nuclear mutants resulting from homologous recombination with this method remained very challenging. Recently, a modified glass bead transformation protocol was introduced and used for simple generation of chloroplast mutants (Economou et al. 2014).

\section{Application of electric fields}

The short application of high intensity electrical fields during electroporation leads to reversible membrane breakdown and concomitant entry of exogenous DNA. This method has been applied successfully to introduce DNA into the nucleus of cells both with and without cell walls (Brown et al. 1991; Shimogawara et al. 1998). Zhang et al. demonstrated that the DNA insertion occurs at apparently random loci and subsequent insertion site sequence analyses indicated that endonucleolytic events during mutagenesis can occur and lead to cleavage of 
the transforming DNA, as well as genomic DNA from lysed cells before integration (Zhang et al. 2014). Numbers on the relative frequencies of homologous vs. nonhomologous integration events after electroporation do not seem to be publicly available. It should be noted that electroporation was also successfully applied to introduce exogenous proteins into C. reinhardtii (Hayashi et al. 2001).

Besides the three main methods, two further strategies to introduce compounds into $C$. reinhardtii have been mentioned in the literature. Kumar et al. described that T-DNA transformation mediated by Agrobacterium tumefaciens was successful (Kumar et al. 2004), but hardly any further study applying this method has been published. Mechanical microinjection of $\mathrm{KCl}$ and $\mathrm{MgSO}_{4}$ solutions into C. reinhardtii was performed even before the first successful DNA transformation (Nichols and Rikmenspoel 1978), but was apparently not yet applied for nucleic acid transfer. Very recently, the novel method of live-cell nanoinjection of fluorescent probes (Hennig et al. 2015) was successfully applied with cell-wall deficient $C$. reinhardtii cells (unpublished data in cooperation with Dr. S. Hennig and Prof. Dr. T. Huser, Bielefeld University, 2014). Although both, micro- and nanoinjection are not feasible for high-throughput macromolecular transfer, direct injection could become interesting alternatives to deliver molecular tools when generation of a genetically modified organism is not desired.

\section{(2) Cell line selection for genetic engineering}

Located at the University of Minnesota, the Chlamydomonas Resource Center houses a large collection of Chlamydomonas cell lines, which is of great value because it facilitates the selection of appropriate cell lines for specific scientific tasks. In the context of genetic engineering, three issues of general importance should be considered. First, it is important to decide if a cell wall or a cell wall deficient strain should be preferred. As mentioned before, transformation via vortexing methods is very simple in the case of cell wall deficient strains, however, the presence of a cell wall can be beneficial in terms of cell robustness, an important parameter for many biotechnological applications. Second, the strategy of transformant selection must be taken into account. Complementation of mutant cell lines or transformation of dominant selectable markers are the two most common ways for positive transformant identification. When complementation (e.g. transformation of an arginine auxotrophic strain like CC1618 with an argininosuccinate lyase containing plasmid) is applied, it must be considered that in all subsequent experiments, growth of the parental strain has to be supplemented continuously with arginine, in contrast to the complemented strain. Since it is likely that the intracellular level of the supplemented substance will vary between wt and mutant, subsequent phenotype analyses can be misleading. For certain physiological experiments, it therefore seems more practical to use a non-auxotrophic parental stain and a marker conferring antibiotic resistance, since after initial selection, the antibiotic can be omitted from subsequent phenotype analyses, minimizing potential unwanted side effects. Third, the cell line dependent efficiency of transgene expression is often low (Fuhrmann et al. 1999; Schroda et al. 2000). Improved transgene expression was recently described for two cell lines, designated UVM4 and UVM11, which were isolated after UV mutagenesis of the cell wall deficient parental strain cw15-302 (Neupert et al. 2009). Alterations of the chromatin structure are suggested to be the reason for the improved transgene expression with these strains, but the exact molecular basis is still unknown (Neupert et al. 2009). Very recently, the strain METI, an insertional mutant of a putative maintenance-type DNA cytosine methyltransferase, was identified to also show improved transgene expression characteristics (Kong et al. 2015). 


\section{(3) Target effect of genetic tool application}

Molecular genetic tools are generally applied to achieve one of two apparently opposite goals, (a) the facilitation or enhancement of target gene expression or (b) the reduction of expression or editing of an endogenous gene target. Most genetic tools and techniques therefore fall into one of the two categories, although some tool elements can be adapted for dual use.

a) Tools and techniques for endogenous and exogenous gene expression

Stable and efficient transgene expression in $C$. reinhardtii has been notoriously difficult, especially from the nucleus (Fuhrmann et al. 1999; Neupert et al. 2009). Potential reasons are biased codon usage (Heitzer et al. 2007), epigenetic transgene silencing (Cerutti et al. 1997), positional effects and chromatin structure (Specht et al. 2014; Strenkert et al. 2011), aberrant processing, lack of suitable regulatory sequences or potentially further currently unknown mechanisms (Fuhrmann et al. 1999). Efficient transgene expression strongly relies on noncoding, cis-acting elements (Barnes et al. 2005; Lumbreras et al. 1998; Sizova et al. 2001) and several elements promoting stable transgene expression have been identified.

\section{Promoters}

Promoters drive gene expression and many promoter/5' untranslated regions (UTRs) have successfully been used for recombinant transgene expression. At present, the hybrid HSP70A-RBCS2 promoter (Schroda et al. 2000), in combination with one or more enhancing introns, is most commonly used if high nuclear transgene expression is desired. For this reason, we selected this hybrid system to develop a versatile, modular vector tool for nuclear encoded recombinant protein production (Lauersen et al. 2013; Lauersen et al. 2015). A 1,425 bp promoter/5'-UTR region upstream of the endogenous ARG7 gene was recently demonstrated to convey promoter activity of similar strength as the hybrid HSP70A-RBCS2 promoter in the context of an ARS2 reporter assay (Specht et al. 2014), therefore representing an interesting alternative. Promoter trapping (Haring and Beck 1997) has also been performed and led to the identification of several efficient regulatory promoter sequences (Vila et al. 2012). As an example, the UBIRP (ubiquitine regulatory protein) promoter region, without further improvement, yielded $70 \%$ of the transcript level compared with the HSP70A/RBCS2 hybrid control construct (Vila et al. 2012). It can be expected that systematic analyses and introduction of selected modifications of these and other new promoter sequences will lead to the development of even better systems for high nuclear transgene expression in the near future. An extended overview of nuclear and chloroplast promoters is presented in Supplementary Table S1.

\section{Introns}

Most natural nuclear encoded $C$. reinhardtii genes contain one or more introns, suggesting that intron-exon gene organization is of great relevance for the organism. Indeed, the presence of introns has been shown to potentially exert a strong influence on the efficiency of transgene expression (Lumbreras et al. 1998). Eichler-Stahlberg et al. performed a semi-systematic analysis on the influence of RBCS2 introns on transgene reporter expression. A luciferase-based assay showed that incorporation of one or more RBCS2 introns can lead to increased levels of reporter activity and the highest activity was determined when introns 1, 2 and 3 were present in their physiological order, resulting in a more than fourfold increase of transgene expression (Eichler-Stahlberg et al. 
2009). These data indicated that the selective integration of introns within the transgene construct can be of great importance for high-level transgene expression.

In most cases, the $3^{\prime}$-UTR seems less important in terms of gene expression regulation and several different, e.g. the RBCS2, the PSAD or the psbA 3'-UTRs, have been used successfully for nuclear or chloroplast gene expression, respectively (Bertalan et al. 2015; Fischer and Rochaix 2001; Fuhrmann et al. 2004).

\section{Modulation of transgene expression}

Many of the promoters listed in Supplementary Table S1 show varying activity depending on the prevailing conditions, allowing modulation of transgene expression to some degree. However, molecular tools for efficient and reversible "on/off" transgene expression are rare. The endogenous nuclear cytochrome $\mathrm{c}_{6}$ promoter was successfully used by Quinn et al. for this purpose, since the promoter activity is repressed in the presence of copper but expression is strongly induced upon nickel addition or complete absence (below nanomolar levels) of copper (Quinn et al. 2003). Building on this nuclear promoter, an inducible and repressible chloroplast gene expression tool was developed by Surzycki and colleagues. Here, a nuclear NAC2 mutant was complemented with the NAC2 gene controlled by the cytochrome $\mathrm{c}_{6}$ promoter. Presence of NAC2 is essential for photosynthesis, because the NAC2 protein targets to the chloroplast and stabilizes the 5'-UTR of the chloroplast psbD gene, allowing accumulation of functional photosystem II complexes (Nickelsen et al. 1994). Controlled induction or repression of NAC2 therefore allowed reversible induction or repression of photosynthetic competence, respectively, in the transformant cell lines (Surzycki et al. 2007). Importantly, this regulation principle can be implemented for any coding sequence in the chloroplast by fusing the transgene with the psbD 5'-untranslated region (Surzycki et al. 2007).

Another element for transgene expression regulation was introduced by Croft and colleagues. Thiamine pyrophosphate (TPP) dependent riboswitches were identified and it was shown that inclusion of the THI4 riboswitch leads to repression of recombinant protein production in the presence of TPP (Croft et al. 2007).

A combinatory strategy by Ramundo et al., where the NAC2 gene was placed under the control of the nuclear METE promoter (repression by vitamin $\mathrm{B}_{12}$ ) and the THI4 riboswitch (repression by thiamine), led to the establishment of a vitamin-mediated, reversible chloroplast gene expression/repression tool (Ramundo et al. 2013).

An interesting option to increase nuclear promoter activity is the use of transcription activator-like effector (TALE) proteins and artificially designed TALE proteins were successfully used in $C$. reinhardtii to activate endogenous gene expression (Gao et al. 2015; Gao et al. 2014). The TALE-based technique represents a potential dual purpose tool, since coupling of TALEs with nuclease domains (TALEN) can be applied for specific gene knockout approaches, as will be discussed later.

\section{Transformation markers and reporters}

Early transgene expression trials relied on mutant complementation as a means to identify positive transformants but since then, a variety of dominant selectable markers/reporters for wt nuclear and chloroplast transformation has been established. It should be noted that in contrast to nuclear targets, marker-free and marker-removal strategies exist for chloroplast transformation approaches (Chen and Melis 2013; Day and GoldschmidtClermont 2011; Economou et al. 2014), which can be an important feature for applied biotechnological production processes. 
Nuclear and chloroplast markers/reporters established for $C$. reinhardtii can be grouped into three main categories: (i) Markers complementing a specific (auxotrophic) phenotype; (iia) Markers mediating antibiotic/herbicide resistance by expression of a mutated, endogenous C. reinhardtii gene; (iib) Markers mediating antibiotic/herbicide resistance by expression of a foreign transgene; (iiia) Markers allowing color or (iiib) light emission detection. Supplementary Table S2 presents an extended overview of available options for each category. Amongst the nine markers belonging to category (iib), the ble marker is quite unusual. In contrast to the other eight, it does not represent an enzyme but instead a small, non-catalytic protein, which accumulates in the cell nucleus after expression (Fuhrmann et al. 1999) and directly binds and sequesters the respective DNAcutting antibiotic (e.g. bleomycin) in a dose-dependent, linear stoichiometry (Dumas et al. 1994).

Simultaneous use of two separate plasmids for nuclear transformation can lead to co-transformation of both plasmids into a single cell and this feature was routinely applied in the past to co-transform genes present on plasmids which lacked a dominant selectable marker. However, due to the progress in plasmid construction strategies and the decline of costs for de novo DNA synthesis, expression vectors today incorporate distinct (in some cases easily exchangeable) dominant selectable markers which confer resistance to antibiotics like emetine, hygromycin B, paromomycin or zeo(my)cin, complement an auxotrophic phenotype or restore photosynthesis, alleviating the need for co-transformation (Berthold et al. 2002; Fischer and Rochaix 2001; Heitzer and Zschoernig 2007; Lauersen et al. 2015).

The establishment of several dominant positive selectable markers allows multiple transgene expression within a single cell by subsequent transformations. As an alternative, Rasala et al. employed viral 2A peptides to express multi-cistronic transgenes (Rasala et al. 2014; Rasala et al. 2012), representing an important step towards more complex metabolic engineering approaches.

In contrast to positive selectable markers, negative selectable markers represent factors that confer sensitivity towards a certain compound once expressed in the host cell and can be useful e.g. to identify trans-acting factors (Young and Purton 2014) or as markers for gene silencing approaches (Jiang et al. 2014; Rohr et al. 2004). Three established negative selectable marker in $C$. reinhardtii are the endogenous MAA7 gene (encoding the tryptophan synthase $B$ subunit; presence leads to sensitivity to 5-fluoroindole) (Rohr et al. 2004), the endogenous FKBP12 gene (encoding the 12-kD FK506-binding protein; presence leads to sensitivity to rapamycin) (Crespo et al. 2005) and the E. coli codA gene (encoding cytosine deaminase; presence leads to sensitivity to 5fluorocytosine) (Young and Purton 2014).

\section{b) Tools and techniques to reduce gene expression or edit an endogenous target}

The prevalence of homologous DNA recombination within the organelles makes gene engineering and subsequent functional protein characterization comparably easy. Generation and isolation of specific knockdown or knockout mutants of nuclear encoded genes is substantially more difficult and many techniques were tested in forward or reverse genetics approaches but even today, targeted nuclear gene modification remains very challenging. Since an elaborate topical review was published very recently (Jinkerson and Jonikas 2015), a condensed summary in this respect will be presented here.

\section{Random mutagenesis}

Random mutagenesis of $C$. reinhardtii by DNA insertion or chemical/radiation mutagenesis is comparably easy and it is possible to generate large random mutant collections with several thousands of individual mutants. DNA 
insertion has the advantage that knowledge of the transferred DNA sequence can be exploited for subsequent two large transformant libraries (ca. 22,000 and 100,000 transformant lines, respectively) was published by Gonzalez-Ballester and colleagues. In their work, cells and DNA were systematically pooled to allow subsequent isolation of specific insertion mutants. Briefly, 96 individual transformant lines were pooled and genomic DNA was extracted from each pool. DNA superpools were then prepared by mixing equal volumes of genomic DNA from ten different pools and it was shown that these DNA superpools can be used as templates for PCR screenings, with one primer derived from the marker gene and the other from the nuclear target region. Once a positive signal was detected in a DNA superpool, it was possible to trace it back to the original transformant by sequential PCR and finally colony PCR reactions (Gonzalez-Ballester et al. 2011).

Dent et al. applied random DNA insertion mutagenesis in a forward genetics approach. Approximately 49,000 transformants were generated and phenotypically pre-screened, significantly reducing the number of cell lines that had to be maintained. Different PCR-based techniques were then applied for molecular analyses of the insertion sites and 459 flanking sequence tags could be identified for 439 mutants (Dent et al. 2015).

A general disadvantage of DNA insertion mutagenesis for generation of specific knockout lines is that multicopy insertions, DNA truncations, rearrangements or loss of relatively large regions of the nuclear genome insertion site are not uncommon (Tam and Lefebvre 1993) and can make subsequent assignment of the mutant phenotype difficult. In this context, Zhang et al. recently used a PCR-based high-throughput genotyping method designated ChlaMmeSeq (Chlamydomonas MmeI-based insertion site Sequencing) to analyze 11,478 nuclear insertion sites and showed that endonucleolytic cleavage of the transforming DNA regularly occurs, potentially resulting in identification of misleading flanking sequences (Zhang et al. 2014).

Unambiguous identification of the locus responsible for a specific phenotype after mutation with chemicals or radiation, e.g. by traditional or PCR-based genetic mapping (Jinkerson and Jonikas 2015), is quite challenging because no obvious molecular tag is present and depending on the dose of the mutagen, many DNA mutations may occur in a single cell. TILLING (targeting induced local lesions in genomes) is a method to identify point mutations (Kurowska et al. 2011; McCallum et al. 2000) and one report describes successful application with $C$. reinhardtii to identify a LHCSR1 mutant (Truong 2011). However, this method has since then not been widely applied. Whole genome sequencing and bioinformatic data analyses were recently introduced as an alternative strategy to identify single nucleotide polymorphisms and specific point mutations in C. reinhardtii (Dutcher et al. 2012; Schierenbeck et al. 2015).

A noteworthy general obstacle when working with large random mutant populations is that maintenance of cell cultures requires regular, expensive and work intensive cell transfer and cryopreservation (Crutchfield et al. 1999) is not perfectly reliable for every C. reinhardtii cell line. Targeted gene silencing is an alternative approach and avoids such large mutant library maintenance.

\section{Targeted gene silencing and gene editing}

Several strategies exist to obtain cell lines with specifically reduced gene expression. RNA interference (RNAi) has been shown to be effective in C. reinhardtii (Schroda et al. 1999) and Rohr et al. have introduced the Maa7/X-IR (NE-537) plasmid tool, which allows easy application of the RNAi technology (Rohr et al. 2004). This procedure can also be used to effectively knockdown several homologous genes or even whole gene families (Mussgnug et al. 2007). In 2009, two artificial micro-RNA (amiRNA) gene knockdown tools were 
introduced for C. reinhardtii, one based on the endogenous micro-RNA precursor MIR1162 (Zhao et al. 2009), by Molnar et al., in combination with the web-based WMD software (Ossowski et al. 2008), allowed userfriendly application and was subsequently modified to generate an inducible amiRNA tool by replacing the original HSP70A-RBCS2 hybrid promoter with the NIT1 promoter (Schmollinger et al. 2010). Most recently, $\mathrm{Hu}$ et al. published an alternative amiRNA tool, which includes a luciferase reporter, and a one-step construction option for the amiRNA precursor (Hu et al. 2014).

A general downside of knockdown approaches is that RNAi efficiency and stability are transformant-specific and often complete silencing cannot be reached or maintained. Residual transcript expression can be advantageous for studies of essential genes, but on the other hand can make phenotype analyses difficult.

The generation of specific knockout mutants and/or targeted nuclear genome engineering can be achieved via directed endonucleolytic DNA cleavage. In case of DNA damage repair via error-prone non-homologous end joining, deletion or insertions commonly occur and often result in gene inactivation (Carroll 2014). If the DNA break is instead repaired via homologous recombination, addition of synthesized homologous DNA fragments, which contain a modified version of the target gene, can be utilized for targeted gene editing (Carroll 2014). To create such tools, highly DNA sequence specific nucleases have to be designed. The three most prominent strategies today are based on zinc-finger nucleases (ZFNs), TALEN or on the bacterial clustered regularly interspaced short palindromic repeats (CRISPR)/CRISPR-associated (Cas) system. The ZNF and the TALEN approaches both rely on engineering and fusion of specific DNA-binding protein domains (zinc-fingers or TALEs) to the FokI nuclease domain. In contrast, specificity of the Cas9 nuclease is guided by RNA in the CRISPR/Cas system. The latter is clearly superior to ZNFs and TALENs with regard to the simplicity of target design, allowing fast and easy adaption, however, off-target DNA cleavage can be quite problematic (Carroll 2014).

Advances to introduce nuclease-based tools to C. reinhardtii were, to some degree, made for all three approaches but today, the most developed option is the use of ZFNs and Sizova et al. successfully applied this method to target the COP3 gene (Sizova et al. 2013). As mentioned before, functional TALE proteins have been used in Chlamydomonas for gene expression activation (Gao et al. 2015; Gao et al. 2014) however, nuclease coupling and subsequent successful application for targeted gene knockout was not yet demonstrated.

The first trials to introduce the CRISPR/Cas tool to $C$. reinhardtii by Jiang et al. showed that the system is in principle functional, but lack of surviving transformants led the authors to conclude that Cas9 expression could be toxic to the cells (Jiang et al. 2014). This conclusion was recently challenged by work from the Hegemann lab (Humboldt University Berlin). Greiner provided evidence that in vivo expression of a Cas9-YFP fusion protein in C. reinhardtii was indeed possible and furthermore demonstrated specific Cas9 nuclease activity (Greiner 2014).

\section{Summary}

C. reinhardtii represents the most established eukaryotic microalgal model organism for fundamental and applied research. Many genetic tool elements and elaborate techniques have been developed and today, researchers often can select from several options to achieve a certain genetic engineering goal. Table 1 provides a bullet point style summary of the respective key topics addressed in this article and lists several considerations which are important for the selection of appropriate genetic engineering strategies for C. reinhardtii. 


\section{Trends and prospects}

As summarized in this review, substantial progress in the development of $C$. reinhardtii genetic engineering has been made in the past and numerous successful examples of genetic tool applications are published. However, not all of the tools and techniques can easily be implemented to new targets, because many were initially developed for a specific purpose, rather than for versatile use. The recent progress in the field of DNA synthesis technology has led to a dramatic reduction of the costs for gene synthesis, making the desirable rational redesign for optimal versatility of certain genetic tools feasible.

A major limitation still is the lack of tools for quick generation and isolation of distinct nuclear knockout mutants. Major progress can be expected from an indexed and mapped insertional mutant library prepared via the ChlaMmeSeq approach, which is currently in development (Jinkerson and Jonikas 2015).

The CRISPR/Cas9 system is the most valuable new tool for targeted nuclear genome editing in many species, but initial trials have indicated that the adaptation to Chlamydomonas could be comparatively difficult (Jiang et al. 2014). It can still be expected that a fully functional CRISPR/Cas tool will eventually be established and since the spectrum of applications for this tool is not limited to the generation of knockout mutants or gene editing (Mali et al. 2013), many more exciting applications can be foreseen once this has been achieved.

The ongoing progress of genetic tool development also paves the way for new approaches of metabolic pathway engineering, which often require multiple genetic engineering steps in plants (Bock 2013). It therefore seems likely that many ideas to change the metabolic composition or to produce novel compounds in C. reinhardtii will be realized in the near future.

Cloning and maintenance of large DNA fragments in yeast, including the complete $C$. reinhardtii chloroplast genome (O'Neill et al. 2012) and even entire chromosomes of Phaeodactylum tricornutum (Karas et al. 2013), have already been demonstrated and the further implementation of synthetic genomic approaches and modular functional device strategies, as illustrated by Scaife and colleagues with an example for improved triacylglycerol biosynthesis (Scaife et al. 2015), become realistic concepts.

\section{Acknowledgments}

I thank Prof. C. Remacle, Prof. R. Bassi, Prof. P. Hegemann and Dr. A. Greiner for valuable comments on specific topics, Dr. L. Wobbe for critical assessment and the German state North Rhine-Westphalia for funding.

\section{Conflict of interest}

I declare no conflict of interest.

\section{References}

Allahverdiyeva Y, Suorsa M, Tikkanen M, Aro EM (2014) Photoprotection of photosystems in fluctuating light intensities. J Exp Bot. doi: 10.1093/jxb/eru463 
Barnes D, Franklin S, Schultz J, Henry R, Brown E, Coragliotti A, Mayfield SP (2005) Contribution of 5 '- and 3 '-untranslated regions of plastid mRNAs to the expression of Chlamydomonas reinhardtii chloroplast genes. Mol Genet Genomics 274:625-636

Bertalan I, Munder MC, Weiss C, Kopf J, Fischer D, Johanningmeier U (2015) A rapid, modular and markerfree chloroplast expression system for the green alga Chlamydomonas reinhardtii. J Biotechnol 195:6066

Berthold P, Schmitt R, Mages W (2002) An engineered Streptomyces hygroscopicus aph 7" gene mediates dominant resistance against hygromycin B in Chlamydomonas reinhardtii. Protist 153:401-412

Blaby-Haas CE, Merchant SS (2012) The ins and outs of algal metal transport. Bba-Mol Cell Res 1823:15311552

Blaby IK, Blaby-Haas CE, Tourasse N, Hom EFY, Lopez D, Aksoy M, Grossman A, Umen J, Dutcher S, Porter M, King S, Witman GB, Stanke M, Harris EH, Goodstein D, Grimwood J, Schmutz J, Vallon O, Merchant SS, Prochnik S (2014) The Chlamydomonas genome project: a decade on. Trends Plant Sci 19:672-680

Bock R (2013) Strategies for metabolic pathway engineering with multiple transgenes. Plant Mol Biol 83:21-31

Boynton JE, Gillham NW, Harris EH, Hosler JP, Johnson AM, Jones AR, Randolph-Anderson BL, Robertson D, Klein TM, Shark KB, Sanford JC (1988) Chloroplast transformation in Chlamydomonas with high velocity microprojectiles. Science 240:1534-1538

Brown LE, Sprecher SL, Keller LR (1991) Introduction of exogenous DNA into Chlamydomonas reinhardtii by electroporation. Mol Cell Biol 11:2328-2332

Cardol P, Remacle C (2009) The mitochondrial genome. In: Stern DB, Harris EH (eds) The Chlamydomonas Sourcebook. vol 2. Academic Press, p 445-467

Carroll D (2014) Genome engineering with targetable nucleases. Annu Rev Biochem 83:409-439

Cerutti H, Johnson AM, Gillham NW, Boynton JE (1997) Epigenetic silencing of a foreign gene in nuclear transformants of Chlamydomonas. Plant Cell 9:925-945

Chen HC, Melis A (2013) Marker-free genetic engineering of the chloroplast in the green microalga Chlamydomonas reinhardtii. Plant Biotechnol J 11:818-828

Crespo JL, Diaz-Troya S, Florencio FJ (2005) Inhibition of target of rapamycin signaling by rapamycin in the unicellular green alga Chlamydomonas reinhardtii. Plant Physiol 139:1736-1749

Croft MT, Moulin M, Webb ME, Smith AG (2007) Thiamine biosynthesis in algae is regulated by riboswitches. Proc Natl Acad Sci U S A 104:20770-20775

Crutchfield ALM, Diller KR, Brand JJ (1999) Cryopreservation of Chlamydomonas reinhardtii (Chlorophyta). Eur J Phycol 34:43-52

Day A, Debuchy R, Vandillewijn J, Purton S, Rochaix JD (1990) Studies on the maintenance and expression of cloned DNA fragments in the nuclear genome of the green alga Chlamydomonas reinhardtii. Physiol Plantarum 78:254-260

Day A, Goldschmidt-Clermont M (2011) The chloroplast transformation toolbox: selectable markers and marker removal. Plant Biotechnol J 9:540-553

Debuchy R, Purton S, Rochaix JD (1989) The argininosuccinate lyase gene of Chlamydomonas reinhardtii: an important tool for nuclear transformation and for correlating the genetic and molecular maps of the ARG7 locus. Embo J 8:2803-2809

Dent RM, Sharifi MN, Malnoe A, Haglund C, Calderon RH, Wakao S, Niyogi KK (2015) Large-scale insertional mutagenesis of Chlamydomonas supports phylogenomic functional prediction of photosynthetic genes and analysis of classical acetate-requiring mutants. Plant J. doi: 10.1111/tpj.12806

Dumas P, Bergdoll M, Cagnon C, Masson JM (1994) Crystal structure and site-directed mutagenesis of a bleomycin resistance protein and their significance for drug sequestering. Embo J 13:2483-2492

Dunahay TG (1993) Transformation of Chlamydomonas reinhardtii with silicon-carbide whiskers. Biotechniques 15:452-460

Dutcher SK (2014) The awesome power of dikaryons for studying flagella and basal bodies in Chlamydomonas reinhardtii. Cytoskeleton 71:79-94

Dutcher SK, Li L, Lin H, Meyer L, Giddings TH, Jr., Kwan AL, Lewis BL (2012) Whole-genome sequencing to identify mutants and polymorphisms in Chlamydomonas reinhardtii. G3 2:15-22

Ebersold WT (1967) Chlamydomonas reinhardi: heterozygous diploid strains. Science 157:447-449

Economou C, Wannathong T, Szaub J, Purton S (2014) A simple, low-cost method for chloroplast transformation of the green alga Chlamydomonas reinhardtii. Methods Mol Biol 1132:401-411

Ehrenberg CG (1834) Dritter Beitrag zur Erkenntniss grosser Organisation in der Richtung des kleinsten Raumes. Organisation in der Richtung des kleinsten Raumes. Duemmler, Berlin

Eichler-Stahlberg A, Weisheit W, Ruecker O, Heitzer M (2009) Strategies to facilitate transgene expression in Chlamydomonas reinhardtii. Planta 229:873-883

Fischer N, Rochaix JD (2001) The flanking regions of PsaD drive efficient gene expression in the nucleus of the green alga Chlamydomonas reinhardtii. Mol Genet Genomics 265:888-894 
Fuhrmann M, Hausherr A, Ferbitz L, Schodl T, Heitzer M, Hegemann P (2004) Monitoring dynamic expression of nuclear genes in Chlamydomonas reinhardtii by using a synthetic luciferase reporter gene. Plant Mol Biol 55:869-881

Fuhrmann M, Oertel W, Hegemann P (1999) A synthetic gene coding for the green fluorescent protein (GFP) is a versatile reporter in Chlamydomonas reinhardtii. Plant J 19:353-361

Galvan A, Gonzalez-Ballester D, Fernandez E (2007) Insertional mutagenesis as a tool to study genes/functions in Chlamydomonas. In: Leon R, Galvan A, Fernandez E (eds) Transgenic Microalgae as Green Cell Factories. vol 616. Landes Bioscience, p 77-89

Gao H, Wang Y, Fei X, Wright DA, Spalding MH (2015) Expression activation and functional analysis of HLA3, a putative inorganic carbon transporter in Chlamydomonas reinhardtii. Plant J. doi: $10.1111 /$ tpj. 12788

Gao H, Wright DA, Li T, Wang YJ, Horken K, Weeks DP, Yang B, Spalding MH (2014) TALE activation of endogenous genes in Chlamydomonas reinhardtii. Algal Res 5:52-60

Gonzalez-Ballester D, Pootakham W, Mus F, Yang W, Catalanotti C, Magneschi L, de Montaigu A, Higuera JJ, Prior M, Galvan A, Fernandez E, Grossman AR (2011) Reverse genetics in Chlamydomonas: a platform for isolating insertional mutants. Plant Methods 7:24

Greiner A (2014) CRISPR/Cas9 und Zinkfinger-Nukleasen für die gezielte Genstilllegung in Chlamydomonas reinhardtii. Dissertation, Humboldt University Berlin

Grossman A (2000) Acclimation of Chlamydomonas reinhardtii to its nutrient environment. Protist 151:201-224

Grossman AR, Catalanotti C, Yang W, Dubini A, Magneschi L, Subramanian V, Posewitz MC, Seibert M (2011) Multiple facets of anoxic metabolism and hydrogen production in the unicellular green alga Chlamydomonas reinhardtii. New Phytol 190:279-288

Gumpel NJ, Rochaix JD, Purton S (1994) Studies on homologous recombination in the green alga Chlamydomonas reinhardtii. Curr Genet 26:438-442

Haring MA, Beck CF (1997) A promoter trap for Chlamydomonas reinhardtii: development of a gene cloning method using 5' RACE-based probes. Plant J 11:1341-1348

Harris EH (2001) Chlamydomonas as a model organism. Annu Rev Plant Phys 52:363-406

Harris EH (2009) The Chlamydomonas sourcebook: Introduction to Chlamydomonas and its laboratory use, second edn. Academic Press, Oxford

Hayashi M, Hirono M, Kamiya R (2001) Recovery of flagellar dynein function in a Chlamydomonas actin/dynein-deficient mutant upon introduction of muscle actin by electroporation. Cell Motil Cytoskeleton 49:146-153

Heinnickel ML, Grossman AR (2013) The GreenCut: re-evaluation of physiological role of previously studied proteins and potential novel protein functions. Photosynth Res 116:427-436

Heitzer M, Eckert A, Fuhrmann M, Griesbeck C (2007) Influence of codon bias on the expression of foreign genes in microalgae. In: Leon R, Galvan A, Fernandez E (eds) Transgenic Microalgae as Green Cell Factories. vol 616. Landes Bioscience, p 46-53

Heitzer M, Zschoernig B (2007) Construction of modular tandem expression vectors for the green alga Chlamydomonas reinhardtii using the Cre/lox-system. Biotechniques 43:324-332

Hemschemeier A, Happe T (2011) Alternative photosynthetic electron transport pathways during anaerobiosis in the green alga Chlamydomonas reinhardtii. Bba-Bioenergetics 1807:919-926

Hennig S, van de Linde S, Lummer M, Simonis M, Huser T, Sauer M (2015) Instant live-cell super-resolution imaging of cellular structures by nanoinjection of fluorescent probes. Nano Lett 15:1374-1381

Higgs DC (2009) The chloroplast genome. In: Stern DB, Harris EH (eds) The Chlamydomonas Sourcebook. vol 2. Academic Press, p 871-891

Hiramatsu T, Nakamura S, Misumi O, Kuroiwa T, Nakamura S (2006) Morphological changes in mitochondrial and chloroplast nucleoids and mitochondria during the Chlamydomonas reinhardtii (Chlorophyceae) cell cycle. J Phycol 42:1048-1058

Hu JL, Deng X, Shao N, Wang GH, Huang KY (2014) Rapid construction and screening of artificial microRNA systems in Chlamydomonas reinhardtii. Plant J 79:1052-1064

Jiang WZ, Brueggeman AJ, Horken KM, Plucinak TM, Weeks DP (2014) Successful transient expression of Cas9 and single guide RNA genes in Chlamydomonas reinhardtii. Eukaryot Cell 13:1465-1469

Jinkerson RE, Jonikas MC (2015) Molecular techniques to interrogate and edit the Chlamydomonas nuclear genome. Plant J. doi: 10.1111/tpj.12801

Johnson X, Alric J (2013) Central carbon metabolism and electron transport in Chlamydomonas reinhardtii: metabolic constraints for carbon partitioning between oil and starch. Eukaryot Cell 12:776-793

Joint Genome Institute (2015) Phytozome v10.1, Chlamydomonas reinhardtii v5.5, US Department of Energy. http://phytozome.jgi.doe.gov

Karas BJ, Molparia B, Jablanovic J, Hermann WJ, Lin YC, Dupont CL, Tagwerker C, Yonemoto IT, Noskov VN, Chuang RY, Allen AE, Glass JI, Hutchison CA, 3rd, Smith HO, Venter JC, Weyman PD (2013) Assembly of eukaryotic algal chromosomes in yeast. J Biol Eng 7:30 
Kianianmomeni A, Hallmann A (2014) Algal photoreceptors: in vivo functions and potential applications. Planta 239:1-26

Kindle KL (1990) High-frequency nuclear transformation of Chlamydomonas reinhardtii. Proc Natl Acad Sci U S A 87:1228-1232

Kindle KL, Schnell RA, Fernandez E, Lefebvre PA (1989) Stable nuclear transformation of Chlamydomonas using the Chlamydomonas gene for nitrate reductase. J Cell Biol 109:2589-2601

Kong F, Yamasaki T, Kurniasih SD, Hou L, Li X, Ivanova N, Okada S, Ohama T (2015) Robust expression of heterologous genes by selection marker fusion system in improved Chlamydomonas strains. J Biosci Bioeng. doi: 10.1016/j.jbiosc.2015.01.005

Kumar SV, Misquitta RW, Reddy VS, Rao BJ, Rajam MV (2004) Genetic transformation of the green alga Chlamydomonas reinhardtii by Agrobacterium tumefaciens. Plant Sci 166:731-738

Kurowska M, Daszkowska-Golec A, Gruszka D, Marzec M, Szurman M, Szarejko I, Maluszynski M (2011) TILLING: a shortcut in functional genomics. J Appl Genet 52:371-390

Larosa V, Coosemans N, Motte P, Bonnefoy N, Remacle C (2012) Reconstruction of a human mitochondrial complex I mutation in the unicellular green alga Chlamydomonas. Plant J 70:759-768

Lauersen KJ, Berger H, Mussgnug JH, Kruse O (2013) Efficient recombinant protein production and secretion from nuclear transgenes in Chlamydomonas reinhardtii. J Biotechnol 167:101-110

Lauersen KJ, Kruse O, Mussgnug JH (2015) Targeted expression of nuclear transgenes in Chlamydomonas reinhardtii with a versatile, modular vector toolkit. Appl Microbiol Biotechnol 99:3491-3503

Lumbreras V, Stevens DR, Purton S (1998) Efficient foreign gene expression in Chlamydomonas reinhardtii mediated by an endogenous intron. Plant J 14:441-447

Mali P, Esvelt KM, Church GM (2013) Cas9 as a versatile tool for engineering biology. Nat Methods 10:957963

Matsuo T, Ishiura M (2011) Chlamydomonas reinhardtii as a new model system for studying the molecular basis of the circadian clock. Febs Lett 585:1495-1502

Maul JE, Lilly JW, Cui L, dePamphilis CW, Miller W, Harris EH, Stern DB (2002) The Chlamydomonas reinhardtii plastid chromosome: islands of genes in a sea of repeats. Plant Cell 14:2659-2679

McCallum CM, Comai L, Greene EA, Henikoff S (2000) Targeted screening for induced mutations. Nat Biotechnol 18:455-457

Melis A, Seibert M, Ghirardi ML (2007) Hydrogen fuel production by transgenic microalgae. In: Leon R, Galvan A, Fernandez E (eds) Transgenic Microalgae as Green Cell Factories. vol 616. Landes Bioscience, $\mathrm{p}$ 110-121

Merchant SS, Kropat J, Liu BS, Shaw J, Warakanont J (2012) TAG, You're it! Chlamydomonas as a reference organism for understanding algal triacylglycerol accumulation. Curr Opin Biotech 23:352-363

Merchant SS, Prochnik SE, Vallon O, Harris EH, Karpowicz SJ, Witman GB, Terry A, Salamov A, Fritz-Laylin LK, Marechal-Drouard L, Marshall WF, Qu LH, Nelson DR, Sanderfoot AA, Spalding MH, Kapitonov VV, Ren QH, Ferris P, Lindquist E, Shapiro H, Lucas SM, Grimwood J, Schmutz J, Cardol P, Cerutti H, Chanfreau G, Chen CL, Cognat V, Croft MT, Dent R, Dutcher S, Fernandez E, Fukuzawa H, Gonzalez-Ballester D, Gonzalez-Halphen D, Hallmann A, Hanikenne M, Hippler M, Inwood W, Jabbari K, Kalanon M, Kuras R, Lefebvre PA, Lemaire SD, Lobanov AV, Lohr M, Manuell A, Meir I, Mets L, Mittag M, Mittelmeier T, Moroney JV, Moseley J, Napoli C, Nedelcu AM, Niyogi K, Novoselov SV, Paulsen IT, Pazour G, Purton S, Ral JP, Riano-Pachon DM, Riekhof W, Rymarquis L, Schroda M, Stern D, Umen J, Willows R, Wilson N, Zimmer SL, Allmer J, Balk J, Bisova K, Chen CJ, Elias M, Gendler K, Hauser C, Lamb MR, Ledford H, Long JC, Minagawa J, Page MD, Pan JM, Pootakham W, Roje S, Rose A, Stahlberg E, Terauchi AM, Yang PF, Ball S, Bowler C, Dieckmann CL, Gladyshev VN, Green P, Jorgensen R, Mayfield S, Mueller-Roeber B, Rajamani S, Sayre RT, Brokstein P, Dubchak I, Goodstein D, Hornick L, Huang YW, Jhaveri J, Luo YG, Martinez D, Ngau WCA, Otillar B, Poliakov A, Porter A, Szajkowski L, Werner G, Zhou KM, Grigoriev IV, Rokhsar DS, Grossman AR, Annotation C, Team JA (2007) The Chlamydomonas genome reveals the evolution of key animal and plant functions. Science 318:245-251

Minagawa J (2011) State transitions-the molecular remodeling of photosynthetic supercomplexes that controls energy flow in the chloroplast. Bba 1807:897-905

Molnar A, Bassett A, Thuenemann E, Schwach F, Karkare S, Ossowski S, Weigel D, Baulcombe D (2009) Highly specific gene silencing by artificial microRNAs in the unicellular alga Chlamydomonas reinhardtii. Plant J 58:165-174

Mussgnug JH, Thomas-Hall S, Rupprecht J, Foo A, Klassen V, McDowall A, Schenk PM, Kruse O, Hankamer B (2007) Engineering photosynthetic light capture: impacts on improved solar energy to biomass conversion. Plant Biotechnol J 5:802-814

Nelson JAE, Lefebvre PA (1995) Targeted disruption of the NIT8 gene in Chlamydomonas reinhardtii. Mol Cell Biol 15:5762-5769 
Neupert J, Karcher D, Bock R (2009) Generation of Chlamydomonas strains that efficiently express nuclear transgenes. Plant J 57:1140-1150

Nichols KM, Rikmenspoel R (1978) Control of flagellar motion in Chlamydomonas and Euglena by mechanical microinjection of $\mathrm{Mg} 2+$ and $\mathrm{Ca} 2+$ and by electric current injection. J Cell Sci 29:233-247

Nickelsen J, van Dillewijn J, Rahire M, Rochaix JD (1994) Determinants for stability of the chloroplast psbD RNA are located within its short leader region in Chlamydomonas reinhardtii. Embo J 13:3182-3191

Nishimura Y, Higashiyama T, Suzuki L, Misumi O, Kuroiwa T (1998) The biparental transmission of the mitochondrial genome in Chlamydomonas reinhardtii visualized in living cells. Eur J Cell Biol 77:124133

O'Neill BM, Mikkelson KL, Gutierrez NM, Cunningham JL, Wolff KL, Szyjka SJ, Yohn CB, Redding KE, Mendez MJ (2012) An exogenous chloroplast genome for complex sequence manipulation in algae. Nucleic Acids Res 40:2782-2792

Ossowski S, Schwab R, Weigel D (2008) Gene silencing in plants using artificial microRNAs and other small RNAs. Plant J 53:674-690

Pröschold T, Marin B, Schlosser UG, Melkonian M (2001) Molecular phylogeny and taxonomic revision of Chlamydomonas (Chlorophyta). I. Emendation of Chlamydomonas Ehrenberg and Chloromonas Gobi, and description of Oogamochlamys gen. nov and Lobochlamys gen. nov. Protist 152:265-300

Quinn JM, Kropat J, Merchant S (2003) Copper response element and Crr1-dependent Ni2+-responsive promoter for induced, reversible gene expression in Chlamydomonas reinhardtii. Eukaryot Cell 2:9951002

Ramundo S, Rahire M, Schaad O, Rochaix JD (2013) Repression of essential chloroplast genes reveals new signaling pathways and regulatory feedback loops in Chlamydomonas. Plant Cell 25:167-186

Randolph-Anderson BL, Boynton JE, Gillham NW, Harris EH, Johnson AM, Dorthu MP, Matagne RF (1993) Further characterization of the respiratory deficient Dum1 mutation of Chlamydomonas reinhardtii and its use as a recipient for mitochondrial transformation. Mol Gen Genet 236:235-244

Rasala BA, Chao SS, Pier M, Barrera DJ, Mayfield SP (2014) Enhanced genetic tools for engineering multigene traits into green algae. Plos One. doi: 10.1371/journal.pone.0094028

Rasala BA, Lee PA, Shen ZX, Briggs SP, Mendez M, Mayfield SP (2012) Robust expression and secretion of Xylanase 1 in Chlamydomonas reinhardtii by fusion to a selection gene and processing with the FMDV 2A peptide. Plos One. doi: 10.1371/journal.pone.0043349

Rasala BA, Mayfield SP (2015) Photosynthetic biomanufacturing in green algae; production of recombinant proteins for industrial, nutritional, and medical uses. Photosynth Res 123:227-239

Remacle C, Cardol P, Coosemans N, Gaisne M, Bonnefoy N (2006) High-efficiency biolistic transformation of Chlamydomonas mitochondria can be used to insert mutations in complex I genes. Proc Natl Acad Sci U S A 103:4771-4776

Rochaix JD, Lemeille S, Shapiguzov A, Samol I, Fucile G, Willig A, Goldschmidt-Clermont M (2012) Protein kinases and phosphatases involved in the acclimation of the photosynthetic apparatus to a changing light environment. Philos T R Soc B 367:3466-3474

Rochaix JD, van Dillewijn J (1982) Transformation of the green alga Chlamydomonas reinhardii with yeast DNA. Nature 296:70-72

Rohr J, Sarkar N, Balenger S, Jeong BR, Cerutti H (2004) Tandem inverted repeat system for selection of effective transgenic RNAi strains in Chlamydomonas. Plant J 40:611-621

Rosales-Mendoza S, Paz-Maldonado LMT, Soria-Guerra RE (2012) Chlamydomonas reinhardtii as a viable platform for the production of recombinant proteins: current status and perspectives. Plant Cell Rep 31:479-494

Ryan R, Grant D, Chiang KS, Swift H (1978) Isolation and characterization of mitochondrial DNA from Chlamydomonas reinhardtii. Proc Natl Acad Sci U S A 75:3268-3272

Sager R, Granick S (1953) Nutritional studies with Chlamydomonas reinhardi. Ann N Y Acad Sci 56:831-838

Sager R, Granick S (1954) Nutritional control of sexuality in Chlamydomonas reinhardi. J Gen Physiol 37:729742

Salinas T, Larosa V, Cardol P, Marechal-Drouard L, Remacle C (2014) Respiratory-deficient mutants of the unicellular green alga Chlamydomonas: a review. Biochimie 100:207-218

Scaife MA, Nguyen GT, Rico J, Lambert D, Helliwell KE, Smith AG (2015) Establishing Chlamydomonas reinhardtii as an industrial biotechnology host. Plant J. doi: 10.1111/tpj.12781

Schierenbeck L, Ries D, Rogge K, Grewe S, Weisshaar B, Kruse O (2015) Fast forward genetics to identify mutations causing a high light tolerant phenotype in Chlamydomonas reinhardtii by whole-genomesequencing. BMC Genomics 16:57

Schmollinger S, Strenkert D, Schroda M (2010) An inducible artificial microRNA system for Chlamydomonas reinhardtii confirms a key role for heat shock factor 1 in regulating thermotolerance. Curr Genet 56:383-389 
Schroda M, Blocker D, Beck CF (2000) The HSP70A promoter as a tool for the improved expression of transgenes in Chlamydomonas. Plant J 21:121-131

Schroda M, Vallon O, Wollman FA, Beck CF (1999) A chloroplast-targeted heat shock protein 70 (HSP70) contributes to the photoprotection and repair of photosystem II during and after photoinhibition. Plant Cell 11:1165-1178

Schulze T, Prager K, Dathe H, Kelm J, Kiessling P, Mittag M (2010) How the green alga Chlamydomonas reinhardtii keeps time. Protoplasma 244:3-14

Shimogawara K, Fujiwara S, Grossman A, Usuda H (1998) High-efficiency transformation of Chlamydomonas reinhardtii by electroporation. Genetics 148:1821-1828

Shimogawara K, Wykoff DD, Usuda H, Grossman AR (1999) Chlamydomonas reinhardtii mutants abnormal in their responses to phosphorus deprivation. Plant Physiol 120:685-693

Sizova I, Fuhrmann M, Hegemann P (2001) A Streptomyces rimosus aphVIII gene coding for a new type phosphotransferase provides stable antibiotic resistance to Chlamydomonas reinhardtii. Gene 277:221229

Sizova I, Greiner A, Awasthi M, Kateriya S, Hegemann P (2013) Nuclear gene targeting in Chlamydomonas using engineered zinc-finger nucleases. Plant J 73:873-882

Skjanes K, Rebours C, Lindblad P (2013) Potential for green microalgae to produce hydrogen, pharmaceuticals and other high value products in a combined process. Crit Rev Biotechnol 33:172-215

Sodeinde OA, Kindle KL (1993) Homologous recombination in the nuclear genome of Chlamydomonas reinhardtii. Proc Natl Acad Sci U S A 90:9199-9203

Specht EA, Nour-Eldin HH, Hoang KT, Mayfield SP (2014) An improved ARS2-derived nuclear reporter enhances the efficiency and ease of genetic engineering in Chlamydomonas. Biotechnol J. doi: 10.1002/biot.201400172

Strenkert D, Schmollinger S, Sommer F, Schulz-Raffelt M, Schroda M (2011) Transcription factor-dependent chromatin remodeling at heat shock and copper-responsive promoters in Chlamydomonas reinhardtii. Plant Cell 23:2285-2301

Surzycki R, Cournac L, Peltier G, Rochaix JD (2007) Potential for hydrogen production with inducible chloroplast gene expression in Chlamydomonas. Proc Natl Acad Sci U S A 104:17548-17553

Tam LW, Lefebvre PA (1993) Cloning of flagellar genes in Chlamydomonas reinhardtii by DNA insertional mutagenesis. Genetics 135:375-384

Truong TB (2011) Investigating the role(s) of LHCSRs in Chlamydomonas reinhardtii. Dissertation, University of California, Berkeley. http://escholarship.org/uc/item/2154v8x8

Umen JG (2011) Evolution of sex and mating loci: an expanded view from Volvocine algae. Curr Opin Microbiol 14:634-641

Vahrenholz C, Riemen G, Pratje E, Dujon B, Michaelis G (1993) Mitochondrial DNA of Chlamydomonas reinhardtii: the structure of the ends of the linear $15.8-\mathrm{kb}$ genome suggests mechanisms for DNA replication. Curr Genet 24:241-247

Vila M, Diaz-Santos E, de la Vega M, Rodriguez H, Vargas A, Leon R (2012) Promoter trapping in microalgae using the antibiotic paromomycin as selective agent. Mar Drugs 10:2749-2765

Wobbe L, Nixon PJ (2013) The mTERF protein MOC1 terminates mitochondrial DNA transcription in the unicellular green alga Chlamydomonas reinhardtii. Nucleic Acids Res 41:6553-6567

Yamasaki T, Kurokawa S, Watanabe KI, Ikuta K, Ohama T (2005) Shared molecular characteristics of successfully transformed mitochondrial genomes in Chlamydomonas reinhardtii. Plant Mol Biol 58:515-527

Young REB, Purton S (2014) Cytosine deaminase as a negative selectable marker for the microalgal chloroplast: a strategy for the isolation of nuclear mutations that affect chloroplast gene expression. Plant J 80:915925

Zhang R, Patena W, Armbruster U, Gang SS, Blum SR, Jonikas MC (2014) High-throughput genotyping of green algal mutants reveals random distribution of mutagenic insertion sites and endonucleolytic cleavage of transforming DNA. Plant Cell 26:1398-1409

Zhao T, Wang W, Bai X, Qi YJ (2009) Gene silencing by artificial microRNAs in Chlamydomonas. Plant J 58:157-164

Zorin B, Hegemann P, Sizova I (2005) Nuclear-gene targeting by using single-stranded DNA avoids illegitimate DNA integration in Chlamydomonas reinhardtii. Eukaryot Cell 4:1264-1272

Zorin B, Lu YH, Sizova I, Hegemann P (2009) Nuclear gene targeting in Chlamydomonas as exemplified by disruption of the PHOT gene. Gene 432:91-96 
Table 1 Summary of the key topics and respective considerations important for genetic engineering of C. reinhardtii addressed in this article.

\begin{tabular}{|c|c|}
\hline Topic & Considerations \\
\hline $\begin{array}{l}\text { Genomes and } \\
\text { genetic tool } \\
\text { delivery }\end{array}$ & $\begin{array}{l}\text { The genetic content present in mitochondria, chloroplast and nucleus differs significantly in many } \\
\text { aspects and adaptation of transgenes can be advantageous. } \\
\text { All three genomes can be accessed for genetic engineering and the most prominent methods are } \\
\text { biolistic particle bombardment, vortexing and electroporation. } \\
\text { Homologous recombination of the transferred DNA readily occurs in chloroplast and } \\
\text { mitochondria but is a rare event in the nucleus. }\end{array}$ \\
\hline Cell material & $\begin{array}{l}\text { An extensive strain collection is maintained at the Chlamydomonas Resource Center at the } \\
\text { University of Minnesota. } \\
\text { Cell wall reduced cell lines allow easy transformation via vortexing methods, but can be less } \\
\text { robust than cell lines with an intact cell wall. } \\
\text { Existing mutant cell lines can be selected for strategies based on complementation. } \\
\text { Cell lines with superior transgene expression characteristics have been isolated. } \\
\text { Cells of opposite mating types (plus and minus) can be crossed, but not all cell lines mate well. }\end{array}$ \\
\hline $\begin{array}{l}\text { Regulatory } \\
\text { elements }\end{array}$ & $\begin{array}{l}\text { Many genetic elements promoting transgene expression were identified and promoters and introns } \\
\text { have most extensively been investigated. } \\
\text { Modulated or constitutive transgene expression can be achieved. } \\
\text { An extended overview of available promoter options is presented in Supplementary Table S1. }\end{array}$ \\
\hline $\begin{array}{l}\text { Markers and } \\
\text { reporters }\end{array}$ & $\begin{array}{l}\text { The existing positive selectable markers are based on mediation of resistance to harmful } \\
\text { chemicals, complementation of an auxotrophy or restoration of photosynthetic competence. } \\
\text { Several reporters based on color detection or light emission are also established. } \\
\text { An extended overview of available markers and reporters is presented in Supplementary Table } \\
\text { S2. Multiple transgene expression can be achieved by multiple transformations or via multi- } \\
\text { cistronic gene expression. } \\
\text { Three available markers allow negative selection. }\end{array}$ \\
\hline $\begin{array}{l}\text { Random } \\
\text { mutagenesis }\end{array}$ & $\begin{array}{l}\text { DNA insertion and chemical/radiation mutagenesis allows generation of large scale nuclear } \\
\text { mutant libraries. Existing libraries be screened for the availability of specific mutants, but } \\
\text { maintenance of large mutant cell line libraries is work-intensive. } \\
\text { Genotypic analysis of point mutants is more challenging compared to DNA insertion mutants, } \\
\text { because the DNA tag can be exploited for insertion site identification. } \\
\text { Undesired effects including DNA loss and/or rearrangements commonly occur during DNA } \\
\text { insertional mutagenesis. }\end{array}$ \\
\hline $\begin{array}{l}\text { Targeted gene } \\
\text { silencing and } \\
\text { gene editing }\end{array}$ & $\begin{array}{l}\text { Tools are available for generation of knockdown cell lines via RNAi and amiRNA approaches. } \\
\text { ZFNs have successfully been used for specific target knockout. } \\
\text { TALEN and CRISPER/Cas9 tools are under development. }\end{array}$ \\
\hline
\end{tabular}




\section{Supplementary Tables}

Supplementary Table S1 List of promoters described for recombinant transgene and/or reporter gene expression in $C$. reinhardtii from nuclear (n) or chloroplast (c) genomes, respectively. Alternative names are indicated in brackets.

\begin{tabular}{|c|c|c|c|}
\hline Name & Organism, annotation & $\mathbf{n} / \mathbf{c}$ & References \\
\hline 16S rRNA & C. reinhardtii, $16 \mathrm{~S}$ rRNA gene & $\mathrm{c}$ & Klein et al. 1992; Rasala et al. 2011 \\
\hline ARG7 & C. reinhardtii, argininosuccinate lyase & $\mathrm{n}$ & Specht et al. 2014 \\
\hline atpA & $\begin{array}{l}\text { C. reinhardtii, } \\
\text { atp synthase subunit }\end{array}$ & $\mathrm{c}$ & $\begin{array}{l}\text { Blowers et al. 1990; Mayfield et al. } \\
\text { 2003; Michelet et al. } 2011\end{array}$ \\
\hline atpB & C. reinhardtii, atp synthase subunit & $\mathrm{c}$ & Blowers et al. 1990; Klein et al. 1992 \\
\hline ATX1 & C. reinhardtii, copper chaperone antioxidant & $\mathrm{n}$ & Fei and Deng 2007 \\
\hline ß2TUB & C. reinhardtii, $\beta 2$-tubulin & $\mathrm{n}$ & Brunke et al. 1984 \\
\hline $\mathrm{C} 3$ & C. reinhardtii, $\mathrm{C} 3$ & $\mathrm{n}$ & Voytsekh et al. 2008 \\
\hline CAH1 & C. reinhardtii, carbonic Anhydrase & $\mathrm{n}$ & Ferrante et al. 2011; Kucho et al. 1999 \\
\hline $\begin{array}{l}\text { CaMV } \\
35 \mathrm{~S}\end{array}$ & $\begin{array}{l}\text { Cauliflower mosaic virus, } \\
35 \mathrm{~S}\end{array}$ & $\mathrm{n}$ & $\begin{array}{l}\text { Guilley et al. 1982; Kumar et al. 2004; } \\
\text { Ruecker et al. } 2008\end{array}$ \\
\hline CHOP2 & C. reinhardtii, channelopsin-2 & $\mathrm{n}$ & Fuhrmann et al. 2004 \\
\hline CPX1 & C. reinhardtii, coproporphyrinogen oxidase & $\mathrm{n}$ & Quinn et al. 2003 \\
\hline CYC6 & C. reinhardtii, cytochrome $\mathrm{c}_{6}$ & $\mathrm{n}$ & Ferrante et al. 2011; Quinn et al. 2003 \\
\hline FDX5 & C. reinhardtii, ferredoxin & $\mathrm{n}$ & Lambertz et al. 2010 \\
\hline $\begin{array}{l}\text { FEA1 } \\
(\mathrm{H} 43)\end{array}$ & $\begin{array}{l}\text { C. reinhardtii, } \\
\text { FEA1 (H43) }\end{array}$ & $\mathrm{n}$ & $\begin{array}{l}\text { Baba et al. } 2011 \\
\text { Fei et al. } 2009\end{array}$ \\
\hline FOX1 & C. reinhardtii, multi-copper oxidase & $\mathrm{n}$ & Deng et al. 2014 \\
\hline FTR1 & C. reinhardtii, iron transporter & $\mathrm{n}$ & Fei et al. 2010 \\
\hline $\begin{array}{l}\text { GPXH } \\
\text { (GPX5) }\end{array}$ & $\begin{array}{l}\text { C. reinhardtii, } \\
\text { glutathione peroxidase }\end{array}$ & $\mathrm{n}$ & Leisinger et al. 2001 \\
\hline HSP70A & C. reinhardtii, heat shock factor 1 & $\mathrm{n}$ & Schroda et al. 2000 \\
\hline $\begin{array}{l}\text { HSP70A/ } \\
\text { RBCS2 }\end{array}$ & $\begin{array}{l}\text { C. reinhardtii, } \\
\text { hybrid promoter HSP70A/RBCS2 }\end{array}$ & $\mathrm{n}$ & $\begin{array}{l}\text { Lodha et al. 2008; Schroda et al. 2000; } \\
\text { Strenkert et al. } 2013\end{array}$ \\
\hline $\begin{array}{l}\text { HSP70A/ } \\
\text { RBCS3 }\end{array}$ & $\begin{array}{l}\text { Volvox carteri, } \\
\text { hybrid promoter HSP70A/RBCS3 }\end{array}$ & $\mathrm{n}$ & Hallmann and Wodniok 2006 \\
\hline HYDA1 & C. reinhardtii, $[\mathrm{FeFe}]-$ hydrogenase isoform1 & $\mathrm{n}$ & Pape et al. 2012 \\
\hline LHCBM6 & $\begin{array}{l}\text { C. reinhardtii, } \\
\text { LHCBM6 (CABII-1, LHCB1) }\end{array}$ & $\mathrm{n}$ & $\begin{array}{l}\text { Blankenship and Kindle 1992; } \\
\text { Hahn and Kück } 1999\end{array}$ \\
\hline LHCBM9 & C. reinhardtii, LHCBM9 & $\mathrm{n}$ & Grewe et al. 2014; Sawyer et al. 2015 \\
\hline LIP & Dunaliella tertiolecta, light-inducible protein & $\mathrm{n}$ & Park et al. 2013 \\
\hline METE & $\begin{array}{l}\text { C. reinhardtii, } \\
\mathrm{B}_{12} \text {-independent methionine synthase }\end{array}$ & $\mathrm{n}$ & $\begin{array}{l}\text { Croft et al. 2005; } \\
\text { Helliwell et al. } 2014\end{array}$ \\
\hline NAB1 & C. reinhardtii, nucleic acid binding protein 1 & $\mathrm{n}$ & Berger et al. 2014 \\
\hline NIT1 & C. reinhardtii, nitrate reductase & $\mathrm{n}$ & Ohresser et al. 1997 \\
\hline nos & Agrobacterium tumefaciens, nopaline synthase & $\mathrm{n}$ & Diaz-Santos et al. 2013; Hall et al. 1993 \\
\hline petA & C. reinhardtii, cytochrome $\mathrm{b}_{6} \mathrm{f}$ subunit & $\mathrm{c}$ & Young and Purton 2014 \\
\hline petD & C. reinhardtii, cytochrome $\mathrm{b}_{6} \mathrm{f}$ subunit & $\mathrm{c}$ & Sakamoto et al. 1993 \\
\hline PSAD & C. reinhardtii, photosystem I subunit & $\mathrm{n}$ & Fischer and Rochaix 2001 \\
\hline $\begin{array}{l}\text { psaA- } \\
\text { exon1 }\end{array}$ & C. reinhardtii, photosystem I subunit & $\mathrm{c}$ & $\begin{array}{l}\text { Michelet et al. 2011; } \\
\text { Young and Purton } 2014\end{array}$ \\
\hline psbA & C. reinhardtii, photosystem II subunit & $\mathrm{c}$ & Michelet et al. 2011 \\
\hline psbA & Various species, photosystem II subunit & $\mathrm{c}$ & Gimpel and Mayfield 2013 \\
\hline psbD & C. reinhardtii, photosystem II subunit & $\mathrm{c}$ & Nickelsen et al. 1994 \\
\hline $\mathrm{rbcL}$ & C. reinhardtii, RUBISCO large subunit & $\mathrm{c}$ & Blowers et al. 1990; Franklin et al. 2002 \\
\hline RBCS2 & C. reinhardtii, RUBISCO small subunit & $\mathrm{n}$ & $\begin{array}{l}\text { Goldschmidt-Clermont and Rahire } \\
\text { 1986; Kozminski et al. } 1993\end{array}$ \\
\hline RBCS2 & Dunaliella tertiolecta, RUBISCO small subunit & $\mathrm{n}$ & Walker et al. 2005 \\
\hline SQD2 & C. reinhardtii, sulphoquinovosyltransferase & $\mathrm{n}$ & Iwai et al. 2014 \\
\hline SV 40 & $\begin{array}{l}\text { Simian virus } 40 \\
\text { early promoter }\end{array}$ & $\mathrm{n}$ & $\begin{array}{l}\text { Hasnain et al. 1985; } \\
\text { Ladygin and Butanaev } 2002\end{array}$ \\
\hline
\end{tabular}


Supplementary Table S2 List of positive transformation markers and reporters developed for C. reinhardtii. The categories (cat.) are: (i) Auxotrophy/mutation complementation markers; (iia) Antibiotic/herbicide resistance mediated by a mutated, endogenous $C$. reinhardtii gene; (iib) Antibiotic/herbicide resistance mediated by a foreign transgene; (iiia) Markers for color or (iiib) light emission detection.

DCMU: 3-(3,4-dichlorophenyl)-1,1-dimethylurea;

DiFMUX $_{2}$ : 6,8-difluoro-4-methylumbelliferyl beta-D-xylobioside; X: 5-Bromo-4-chloro-3-indolyl;

MUG: 4-methylumbelliferyl glucuronide. Alternative names are indicated in brackets.

\begin{tabular}{|c|c|c|c|c|}
\hline Cat. & Name & Organism, annotation & Activity & References \\
\hline (i) & $\begin{array}{l}\mathrm{AC} 29 \\
(\mathrm{ALB} 3.1)\end{array}$ & $\begin{array}{l}\text { C. reinhardtii, } \\
\text { ALBINO3.1 }\end{array}$ & $\begin{array}{l}\text { Complementation of } \\
\text { yellow, acetate-requiring } \\
\text { phenotype }\end{array}$ & $\begin{array}{l}\text { Bellafiore et al. 2002; } \\
\text { Ferris } 1995\end{array}$ \\
\hline (i) & ARG7 & $\begin{array}{l}\text { C. reinhardtii, } \\
\text { argininosuccinate lyase }\end{array}$ & $\begin{array}{l}\text { Complementation of } \\
\text { arginine auxotrophy }\end{array}$ & Debuchy et al. 1989 \\
\hline (i) & ARG9 & $\begin{array}{l}\text { Arabidopsis thalianal } \\
\text { C. reinhardtii, N-acetyl } \\
\text { ornithine aminotransferase }\end{array}$ & $\begin{array}{l}\text { Complementation of } \\
\text { arginine auxotrophy }\end{array}$ & Remacle et al. 2009 \\
\hline (i) & atpB & $\begin{array}{l}\text { C. reinhardtii, } \\
\text { ATP synthase subunit }\end{array}$ & $\begin{array}{l}\text { Restoration of } \\
\text { photosynthetic competence }\end{array}$ & Boynton et al. 1988 \\
\hline (i) & ATPC & $\begin{array}{l}\text { C. reinhardtii, } \\
\text { ATP synthase subunit }\end{array}$ & $\begin{array}{l}\text { Restoration of } \\
\text { photosynthetic competence }\end{array}$ & Smart and Selman 1993 \\
\hline (i) & NIC7 & $\begin{array}{l}\text { C. reinhardtii, } \\
\text { quinolinate synthetase A }\end{array}$ & $\begin{array}{l}\text { Complementation of } \\
\text { nicotinamide auxotrophy }\end{array}$ & $\begin{array}{l}\text { Ferris 1995; } \\
\text { Ferris et al. } 2002\end{array}$ \\
\hline (i) & $\begin{array}{l}\text { NIT1 } \\
\text { (NIA1) }\end{array}$ & $\begin{array}{l}\text { C. reinhardtii, } \\
\text { nitrate reductase }\end{array}$ & $\begin{array}{l}\text { Restoration of growth } \\
\text { on nitrate }\end{array}$ & $\begin{array}{l}\text { Fernandez et al. } 1989 ; \\
\text { Kindle et al. } 1989\end{array}$ \\
\hline (i) & NIT2 & $\begin{array}{l}\text { C. reinhardtii, } \\
\text { nitrogen metabolism } \\
\text { transcription factor }\end{array}$ & $\begin{array}{l}\text { Restoration of growth } \\
\text { on nitrate }\end{array}$ & $\begin{array}{l}\text { Camargo et al. 2007; } \\
\text { Schnell and } \\
\text { Lefebvre } 1993\end{array}$ \\
\hline (i) & OEE1 & $\begin{array}{l}\text { C. reinhardtii, oxygen- } \\
\text { evolving enhancer protein } 1\end{array}$ & $\begin{array}{l}\text { Restoration of } \\
\text { photosynthetic competence }\end{array}$ & $\begin{array}{l}\text { Mayfield and } \\
\text { Kindle } 1990 \\
\end{array}$ \\
\hline (i) & petB & $\begin{array}{l}\text { C. reinhardtii, } \\
\text { cytochrome } \mathrm{b}_{6} \text { f subunit }\end{array}$ & $\begin{array}{l}\text { Restoration of } \\
\text { photosynthetic competence }\end{array}$ & Cheng et al. 2005 \\
\hline (i) & psaA & $\begin{array}{l}\text { C. reinhardtii, } \\
\text { photosystem I subunit }\end{array}$ & $\begin{array}{l}\text { Restoration of } \\
\text { photosynthetic competence }\end{array}$ & Redding et al. 1998 \\
\hline (i) & psaB & $\begin{array}{l}\text { C. reinhardtii, } \\
\text { photosystem I subunit }\end{array}$ & $\begin{array}{l}\text { Restoration of } \\
\text { photosynthetic competence }\end{array}$ & Redding et al. 1998 \\
\hline (i) & psbA & $\begin{array}{l}\text { C. reinhardtii, } \\
\text { photosystem II subunit }\end{array}$ & $\begin{array}{l}\text { Restoration of } \\
\text { photosynthetic competence }\end{array}$ & $\begin{array}{l}\text { Heiss and } \\
\text { Johanningmeier } 1992 \\
\end{array}$ \\
\hline (i) & psbA & $\begin{array}{l}\text { Various species, } \\
\text { photosystem II subunit }\end{array}$ & $\begin{array}{l}\text { Restoration of } \\
\text { photosynthetic competence }\end{array}$ & $\begin{array}{l}\text { Gimpel and } \\
\text { Mayfield } 2013\end{array}$ \\
\hline (i) & PSY & $\begin{array}{l}\text { C. reinhardtii, } \\
\text { phytoene synthase }\end{array}$ & $\begin{array}{l}\text { Restoration of carotenoid- } \\
\text { less phenotype }\end{array}$ & McCarthy et al. 2004 \\
\hline (i) & rbcL & $\begin{array}{l}\text { C. reinhardtii, } \\
\text { RUBISCO large subunit }\end{array}$ & $\begin{array}{l}\text { Restoration of } \\
\text { photosynthetic competence }\end{array}$ & Chen and Melis 2013 \\
\hline (i) & THI10 & $\begin{array}{l}\text { C. reinhardtii, } \\
\text { hydroxyethylthiazole kinase }\end{array}$ & $\begin{array}{l}\text { Complementation of } \\
\text { thiamine auxotrophy }\end{array}$ & $\begin{array}{l}\text { Ferris 1995; } \\
\text { Ferris et al. } 2002\end{array}$ \\
\hline (i) & $\operatorname{tsc} \mathrm{A}$ & $\begin{array}{l}\text { C. reinhardtii, small } \\
\text { chloroplast RNA involved in } \\
\text { psaA trans-splicing }\end{array}$ & $\begin{array}{l}\text { Restoration of } \\
\text { photosynthetic competence }\end{array}$ & $\begin{array}{l}\text { Goldschmidt-Clermont } \\
1991\end{array}$ \\
\hline (iia) & $16 \mathrm{~S}$ rRNA & $\begin{array}{l}\text { C. reinhardtii, } \\
16 \mathrm{~S} \text { rRNA gene }\end{array}$ & $\begin{array}{l}\text { Resistance to } \\
\text { spectinomycin and } \\
\text { streptomycin }\end{array}$ & Newman et al. 1990 \\
\hline (iia) & 23S rRNA & $\begin{array}{l}\text { C. reinhardtii, } \\
23 \mathrm{~S} \text { rRNA gene }\end{array}$ & $\begin{array}{l}\text { Resistance to } \\
\text { erythromycin }\end{array}$ & Newman et al. 1990 \\
\hline (iia) & ALS & $\begin{array}{l}\text { C. reinhardtii, } \\
\text { acetolactate synthase }\end{array}$ & $\begin{array}{l}\text { Resistance to sulfometuron } \\
\text { methyl and related } \\
\text { sulfonylurea herbicides }\end{array}$ & Kovar et al. 2002 \\
\hline
\end{tabular}




\begin{tabular}{|c|c|c|c|c|}
\hline (iia) & CRY1 & $\begin{array}{l}\text { C. reinhardtii, } \\
\text { ribosomal protein } \mathrm{S} 14\end{array}$ & $\begin{array}{l}\text { Resistance to emetine and } \\
\text { cryptopleurine }\end{array}$ & Nelson et al. 1994 \\
\hline (iia) & PDS & $\begin{array}{l}\text { C. reinhardtii, } \\
\text { phytoene desaturase }\end{array}$ & $\begin{array}{l}\text { Resistance to } \\
\text { norflurazon }\end{array}$ & Bruggeman et al. 2014 \\
\hline (iia) & $\begin{array}{l}\text { PPX } \\
\text { (PPO) }\end{array}$ & $\begin{array}{l}\text { C. reinhardtii, } \\
\text { protoporphyrinogen oxidase }\end{array}$ & $\begin{array}{l}\text { Resistance to } \\
\text { oxyfluorfen }\end{array}$ & $\begin{array}{l}\text { Bruggeman et al. 2014; } \\
\text { Randolph-Anderson et } \\
\text { al. } 1998\end{array}$ \\
\hline (iia) & psbA & $\begin{array}{l}\text { C. reinhardtii, } \\
\text { photosystem II subunit }\end{array}$ & $\begin{array}{l}\text { Resistance to } \\
\text { DCMU and metribuzin }\end{array}$ & Przibilla et al. 1991 \\
\hline (iib) & $\operatorname{aadA}$ & $\begin{array}{l}\text { Escherichia coli, } \\
\text { aminoglycoside } \\
\text { adenyltransferase }\end{array}$ & $\begin{array}{l}\text { Resistance to } \\
\text { spectinomycin and } \\
\text { streptomycin }\end{array}$ & $\begin{array}{l}\text { Cerutti et al. 1997; } \\
\text { Goldschmidt-Clermont } \\
\text { 1991; Meslet-Cladiere } \\
\text { and Vallon } 2011\end{array}$ \\
\hline (iib) & aph 7" & $\begin{array}{l}\text { Streptomyces hygroscopicus, } \\
\text { aminoglycoside } \\
\text { phosphotransferase }\end{array}$ & $\begin{array}{l}\text { Resistance to } \\
\text { hygromycin B }\end{array}$ & Berthold et al. 2002 \\
\hline (iib) & aphVIII & $\begin{array}{l}\text { Streptomyces rimosus, } \\
\text { aminoglycoside } \\
\text { phosphotransferase }\end{array}$ & $\begin{array}{l}\text { Resistance to } \\
\text { paromomycin }\end{array}$ & $\begin{array}{l}\text { Sizova et al. 2001; } \\
\text { Sizova et al. } 1996\end{array}$ \\
\hline (iib) & aphA6 & $\begin{array}{l}\text { Acinetobacter baumannii, } \\
\text { aminoglycoside } \\
\text { phosphotransferase }\end{array}$ & $\begin{array}{l}\text { Resistance to } \\
\text { kanamycin and amikacin }\end{array}$ & $\begin{array}{l}\text { Bateman and } \\
\text { Purton } 2000\end{array}$ \\
\hline (iib) & ble & $\begin{array}{l}\text { Streptoalloteichus } \\
\text { hindustanus, } \\
\text { BLE (BRP) protein }\end{array}$ & $\begin{array}{l}\text { Resistance to } \\
\text { bleomycin, phleomycin } \\
\text { and zeo(my)cin }\end{array}$ & $\begin{array}{l}\text { Lumbreras et al. } 1998 ; \\
\text { Stevens et al. } 1996\end{array}$ \\
\hline (iib) & cat & $\begin{array}{l}\text { Transposon } \operatorname{Tn} 9 \text {, } \\
\text { chloramphenicol } \\
\text { acetyltransferase }\end{array}$ & $\begin{array}{l}\text { Resistance to } \\
\text { chloramphenicol }\end{array}$ & Tang et al. 1995 \\
\hline (iib) & gat & $\begin{array}{l}\text { Synthetic glyphosate } \\
\text { acetyltransferase }\end{array}$ & $\begin{array}{l}\text { Resistance to } \\
\text { glyphosate }\end{array}$ & $\begin{array}{l}\text { Bruggeman et al. 2014; } \\
\text { Castle et al. } 2004\end{array}$ \\
\hline (iib) & hpt & $\begin{array}{l}\text { E. coli, hygromycin } \\
\text { phosphotransferase }\end{array}$ & $\begin{array}{l}\text { Resistance to } \\
\text { hygromycin B }\end{array}$ & $\begin{array}{l}\text { Butanaev 1994; } \\
\text { Kumar et al. 2004 }\end{array}$ \\
\hline (iib) & nptII & $\begin{array}{l}\text { Transposon } T n 5 \text {, } \\
\text { neomycin phosphotransferase }\end{array}$ & $\begin{array}{l}\text { Resistance to } \\
\text { kanamycin }\end{array}$ & $\begin{array}{l}\text { An et al. } 1985 \\
\text { Hall et al. } 1993\end{array}$ \\
\hline (iiia) & ARS2 & $\begin{array}{l}\text { C. reinhardtii, } \\
\text { arylsulfatase }\end{array}$ & $\begin{array}{l}\text { Color reaction with } \\
\text { e.g. X-Sulf }\end{array}$ & $\begin{array}{l}\text { Davies et al. 1992; de } \\
\text { Hostos et al. 1989; } \\
\text { Specht et al. } 2014\end{array}$ \\
\hline (iiia/b) & uidA & $\begin{array}{l}\text { Escherichia coli, } \\
\text { ß-glucuronidase }\end{array}$ & $\begin{array}{l}\text { Color from e.g. } \\
\text { X-Gluc or fluorescence } \\
\text { from e.g. MUG substrates }\end{array}$ & $\begin{array}{l}\text { Jefferson et al. } 1987 ; \\
\text { Sakamoto et al. } 1993\end{array}$ \\
\hline (iiib) & xyn1 & $\begin{array}{l}\text { Trichoderma reesei, } \\
\text { xylanase } 1\end{array}$ & $\begin{array}{l}\text { Fluorescence from e.g. } \\
\text { DiFMUX }_{2} \text { substrate }\end{array}$ & Rasala et al. 2012 \\
\hline (iiib) & $\begin{array}{l}\text { BFP, CFP, } \\
\text { GFP, OPF, } \\
\text { RFP, YFP }\end{array}$ & $\begin{array}{l}\text { Entacmaea quadricolor } \\
\text { (blue), Aequorea victoria } \\
\text { (cyan, green, yellow), } \\
\text { Discosoma sp. (orange, red) } \\
\text { fluorescent proteins }\end{array}$ & $\begin{array}{l}\text { Blue, cyan, green, } \\
\text { orange, red or yellow } \\
\text { fluorescence }\end{array}$ & $\begin{array}{l}\text { Franklin et al. 2002; } \\
\text { Fuhrmann et al. 1999; } \\
\text { Lauersen et al. 2015; } \\
\text { Neupert et al. 2009; } \\
\text { Rasala et al. } 2013\end{array}$ \\
\hline (iiib) & $\begin{array}{l}\text { GLUC } \\
\text { RLUC } \\
\text { LUCCP } \\
\text { LUXCT }\end{array}$ & $\begin{array}{l}\text { Gaussia princeps, luciferase } \\
\text { Renilla reniformis, luciferase } \\
\text { Photinus pyralis, luciferase } \\
\text { Vibrio harveyi, luciferase }\end{array}$ & Chemiluminescence & $\begin{array}{l}\text { Fuhrmann et al. 2004; } \\
\text { Matsuo et al. 2006; } \\
\text { Mayfield and Schultz } \\
\text { 2004; Minko et al. 1999; } \\
\text { Ruecker et al. 2008; } \\
\text { Shao and Bock 2008 }\end{array}$ \\
\hline
\end{tabular}




\section{References}

An G, Watson BD, Stachel S, Gordon MP, Nester EW (1985) New cloning vehicles for transformation of higher plants. Embo J 4:277-284

Baba M, Hanawa Y, Suzuki I, Shiraiwa Y (2011) Regulation of the expression of H43/Fea1 by multi-signals. Photosynth Res 109:169-177

Bateman JM, Purton S (2000) Tools for chloroplast transformation in Chlamydomonas: expression vectors and a new dominant selectable marker. Mol Gen Genet 263:404-410

Bellafiore S, Ferris P, Naver H, Gohre V, Rochiax JD (2002) Loss of Albino3 leads to the specific depletion of the light-harvesting system. Plant Cell 14:2303-2314

Berger H, Blifernez-Klassen O, Ballottari M, Bassi R, Wobbe L, Kruse O (2014) Integration of carbon assimilation modes with photosynthetic light capture in the green alga Chlamydomonas reinhardtii. Mol Plant 7:1545-1559

Berthold P, Schmitt R, Mages W (2002) An engineered Streptomyces hygroscopicus aph 7" gene mediates dominant resistance against hygromycin B in Chlamydomonas reinhardtii. Protist 153:401-412

Blankenship JE, Kindle KL (1992) Expression of chimeric genes by the light-regulated cabII-1 promoter in Chlamydomonas reinhardtii: a cabII-1/nit1 gene functions as a dominant selectable marker in a nit1nit2- strain. Mol Cell Biol 12:5268-5279

Blowers AD, Ellmore GS, Klein U, Bogorad L (1990) Transcriptional analysis of endogenous and foreign genes in chloroplast transformants of Chlamydomonas. Plant Cell 2:1059-1070

Boynton JE, Gillham NW, Harris EH, Hosler JP, Johnson AM, Jones AR, Randolph-Anderson BL, Robertson D, Klein TM, Shark KB, Sanford JC (1988) Chloroplast transformation in Chlamydomonas with high velocity microprojectiles. Science 240:1534-1538

Bruggeman AJ, Kuehler D, Weeks DP (2014) Evaluation of three herbicide resistance genes for use in genetic transformations and for potential crop protection in algae production. Plant Biotechnol J 12:894-902

Brunke KJ, Anthony JG, Sternberg EJ, Weeks DP (1984) Repeated consensus sequence and pseudopromoters in the four coordinately regulated tubulin genes of Chlamydomonas reinhardi. Mol Cell Biol 4:1115-1124

Butanaev AM (1994) Use of the hygromycin phosphotransferase gene as the dominant selective marker for Chlamydomonas reinhardtii transformation. Mol Biol (Mosk) 28:1061-1068

Camargo A, Llamas A, Schnell RA, Higuera JJ, Gonzalez-Ballester D, Lefebvre PA, Fernandez E, Galvan A (2007) Nitrate signaling by the regulatory gene NIT2 in Chlamydomonas. Plant Cell 19:3491-3503

Castle LA, Siehl DL, Gorton R, Patten PA, Chen YH, Bertain S, Cho HJ, Duck N, Wong J, Liu DL, Lassner MW (2004) Discovery and directed evolution of a glyphosate tolerance gene. Science 304:1151-1154

Cerutti H, Johnson AM, Gillham NW, Boynton JE (1997) A eubacterial gene conferring spectinomycin resistance on Chlamydomonas reinhardtii: integration into the nuclear genome and gene expression. Genetics 145:97-110

Chen HC, Melis A (2013) Marker-free genetic engineering of the chloroplast in the green microalga Chlamydomonas reinhardtii. Plant Biotechnol J 11:818-828

Cheng Q, Day A, Dowson-Day M, Shen GF, Dixon R (2005) The Klebsiella pneumoniae nitrogenase Fe protein gene (nifH) functionally substitutes for the chlL gene in Chlamydomonas reinhardtii. Biochem Bioph Res Co 329:966-975

Croft MT, Lawrence AD, Raux-Deery E, Warren MJ, Smith AG (2005) Algae acquire vitamin B12 through a symbiotic relationship with bacteria. Nature 438:90-93

Davies JP, Weeks DP, Grossman AR (1992) Expression of the arylsulfatase gene from the beta-2-tubulin promoter in Chlamydomonas reinhardtii. Nucleic Acids Res 20:2959-2965

de Hostos EL, Schilling J, Grossman AR (1989) Structure and expression of the gene encoding the periplasmic arylsulfatase of Chlamydomonas reinhardtii. Mol Gen Genet 218:229-239

Debuchy R, Purton S, Rochaix JD (1989) The argininosuccinate lyase gene of Chlamydomonas reinhardtii: an important tool for nuclear transformation and for correlating the genetic and molecular maps of the ARG7 locus. Embo J 8:2803-2809

Deng XD, Yang JH, Wu XX, Li YJ, Fei XW (2014) A C2H2 zinc finger protein FEMU2 is required for fox1 expression in Chlamydomonas reinhardtii. Plos One. doi: 10.1371/journal.pone.0112977

Diaz-Santos E, de la Vega M, Vila M, Vigara J, Leon R (2013) Efficiency of different heterologous promoters in the unicellular microalga Chlamydomonas reinhardtii. Biotechnol Prog 29:319-328

Fei XW, Deng XD (2007) A novel Fe deficiency-responsive element (FeRE) regulates the expression of atx1 in Chlamydomonas reinharditii. Plant Cell Physiol 48:1496-1503

Fei XW, Eriksson M, Li YJ, Deng XD (2010) A novel negative Fe-deficiency-responsive element and a TGGCA-type-like FeRE control the expression of FTR1 in Chlamydomonas reinhardtii. J Biomed Biotechnol. doi: 10.1155/2010/790247 
Fei XW, Eriksson M, Yang JH, Deng XD (2009) An Fe deficiency responsive element with a core sequence of TGGCA regulates the expression of FEA1 in Chlamydomonas reinharditii. J Biochem 146:157-166

Fernandez E, Schnell R, Ranum LPW, Hussey SC, Silflow CD, Lefebvre PA (1989) Isolation and characterization of the nitrate reductase structural gene of Chlamydomonas reinhardtii. Proc Natl Acad Sci U S A 86:6449-6453

Ferrante P, Diener DR, Rosenbaum JL, Giuliano G (2011) Nickel and low CO2-controlled motility in Chlamydomonas through complementation of a paralyzed flagella mutant with chemically regulated promoters. Bmc Plant Biol. doi: 10.1186/1471-2229-11-22

Ferris PJ (1995) Localization of the nic-7, ac-29 and thi-10 genes within the mating-type locus of Chlamydomonas reinhardtii. Genetics 141:543-549

Ferris PJ, Armbrust EV, Goodenough UW (2002) Genetic structure of the mating-type locus of Chlamydomonas reinhardtii. Genetics 160:181-200

Fischer N, Rochaix JD (2001) The flanking regions of PsaD drive efficient gene expression in the nucleus of the green alga Chlamydomonas reinhardtii. Mol Genet Genomics 265:888-894

Franklin S, Ngo B, Efuet E, Mayfield SP (2002) Development of a GFP reporter gene for Chlamydomonas reinhardtii chloroplast. Plant J 30:733-744

Fuhrmann M, Hausherr A, Ferbitz L, Schodl T, Heitzer M, Hegemann P (2004) Monitoring dynamic expression of nuclear genes in Chlamydomonas reinhardtii by using a synthetic luciferase reporter gene. Plant Mol Biol 55:869-881

Fuhrmann M, Oertel W, Hegemann P (1999) A synthetic gene coding for the green fluorescent protein (GFP) is a versatile reporter in Chlamydomonas reinhardtii. Plant J 19:353-361

Gimpel JA, Mayfield SP (2013) Analysis of heterologous regulatory and coding regions in algal chloroplasts. Appl Microbiol Biot 97:4499-4510

Goldschmidt-Clermont M (1991) Transgenic expression of aminoglycoside adenine transferase in the chloroplast: a selectable marker of site-directed transformation of Chlamydomonas. Nucleic Acids Res 19:4083-4089

Goldschmidt-Clermont M, Rahire M (1986) Sequence, evolution and differential expression of the two genes encoding variant small subunits of Ribulose Bisphosphate Carboxylase/Oxygenase in Chlamydomonas reinhardtii. J Mol Biol 191:421-432

Grewe S, Ballottari M, Alcocer M, D'Andrea C, Blifernez-Klassen O, Hankamer B, Mussgnug JH, Bassi R, Kruse O (2014) Light-harvesting complex protein LHCBM9 is critical for photosystem II activity and hydrogen production in Chlamydomonas reinhardtii. Plant Cell 26:1598-1611

Guilley H, Dudley RK, Jonard G, Balazs E, Richards KE (1982) Transcription of Cauliflower mosaic virus DNA: detection of promoter sequences, and characterization of transcripts. Cell 30:763-773

Hahn D, Kück U (1999) Identification of DNA sequences controlling light- and chloroplast-dependent expression of the lhcb1 gene from Chlamydomonas reinhardtii. Curr Genet 34:459-466

Hall LM, Taylor KB, Jones DD (1993) Expression of a foreign gene in Chlamydomonas reinhardtii. Gene $124: 75-81$

Hallmann A, Wodniok S (2006) Swapped green algal promoters: aphVIII-based gene constructs with Chlamydomonas flanking sequences work as dominant selectable markers in Volvox and vice versa. Plant Cell Rep 25:582-591

Hasnain SE, Manavathu EK, Leung WC (1985) DNA-mediated transformation of Chlamydomonas reinhardi cells: use of aminoglycoside 3'-phosphotransferase as a selectable marker. Mol Cell Biol 5:3647-3650

Heiss S, Johanningmeier U (1992) Analysis of a herbicide resistant mutant Obtained by transformation of the Chlamydomonas chloroplast. Photosynth Res 34:311-317

Helliwell KE, Scaife MA, Sasso S, Araujo AP, Purton S, Smith AG (2014) Unraveling vitamin B12-responsive gene regulation in algae. Plant Physiol 165:388-397

Iwai M, Ikeda K, Shimojima M, Ohta H (2014) Enhancement of extraplastidic oil synthesis in Chlamydomonas reinhardtii using a type-2 diacylglycerol acyltransferase with a phosphorus starvation-inducible promoter. Plant Biotechnol J 12:808-819

Jefferson RA, Kavanagh TA, Bevan MW (1987) GUS fusions: beta-glucuronidase as a sensitive and versatile gene fusion marker in higher plants. Embo J 6:3901-3907

Kindle KL, Schnell RA, Fernandez E, Lefebvre PA (1989) Stable nuclear transformation of Chlamydomonas using the Chlamydomonas gene for nitrate reductase. J Cell Biol 109:2589-2601

Klein U, De Camp JD, Bogorad L (1992) Two types of chloroplast gene promoters in Chlamydomonas reinhardtii. Proc Natl Acad Sci U S A 89:3453-3457

Kovar JL, Zhang J, Funke RP, Weeks DP (2002) Molecular analysis of the acetolactate synthase gene of Chlamydomonas reinhardtii and development of a genetically engineered gene as a dominant selectable marker for genetic transformation. Plant J 29:109-117

Kozminski KG, Diener DR, Rosenbaum JL (1993) High level expression of nonacetylatable alpha-tubulin in Chlamydomonas reinhardtii. Cell Motil Cytoskeleton 25:158-170 
Kucho K, Ohyama K, Fukuzawa H (1999) CO2-responsive transcriptional regulation of CAH1 encoding carbonic anhydrase is mediated by enhancer and silencer regions in Chlamydomonas reinhardtii. Plant Physiol 121:1329-1337

Kumar SV, Misquitta RW, Reddy VS, Rao BJ, Rajam MV (2004) Genetic transformation of the green alga Chlamydomonas reinhardtii by Agrobacterium tumefaciens. Plant Sci 166:731-738

Ladygin VG, Butanaev AM (2002) Transformation of Chlamydomonas reinhardtii CW-15 with the hygromycin phosphotransferase gene as a selective marker. Genetika 38:1196-1202

Lambertz C, Hemschemeier A, Happe T (2010) Anaerobic expression of the ferredoxin-encoding FDX5 gene of Chlamydomonas reinhardtii is regulated by the Crr1 transcription factor. Eukaryot Cell 9:1747-1754

Lauersen KJ, Kruse O, Mussgnug JH (2015) Targeted expression of nuclear transgenes in Chlamydomonas reinhardtii with a versatile, modular vector toolkit. Appl Microbiol Biotechnol 99:3491-3503

Leisinger U, Rufenacht K, Fischer B, Pesaro M, Spengler A, Zehnder AJB, Eggen RIL (2001) The glutathione peroxidase homologous gene from Chlamydomonas reinhardtii is transcriptionally up-regulated by singlet oxygen. Plant Mol Biol 46:395-408

Lodha M, Schulz-Raffelt M, Schroda M (2008) A new assay for promoter analysis in Chlamydomonas reveals roles for heat shock elements and the TATA box in HSP70A promoter-mediated activation of transgene expression. Eukaryot Cell 7:172-176

Lumbreras V, Stevens DR, Purton S (1998) Efficient foreign gene expression in Chlamydomonas reinhardtii mediated by an endogenous intron. Plant J 14:441-447

Matsuo T, Onai K, Okamoto K, Minagawa J, Ishiura M (2006) Real-time monitoring of chloroplast gene expression by a luciferase reporter: evidence for nuclear regulation of chloroplast circadian period. Mol Cell Biol 26:863-870

Mayfield SP, Franklin SE, Lerner RA (2003) Expression and assembly of a fully active antibody in algae. Proc Natl Acad Sci U S A 100:438-442

Mayfield SP, Kindle KL (1990) Stable nuclear transformation of Chlamydomonas reinhardtii by using a $C$. reinhardtii gene as the selectable marker. Proc Natl Acad Sci U S A 87:2087-2091

Mayfield SP, Schultz J (2004) Development of a luciferase reporter gene, luxCt, for Chlamydomonas reinhardtii chloroplast. Plant J 37:449-458

McCarthy SS, Kobayashi MC, Niyogi KK (2004) White mutants of Chlamydomonas reinhardtii are defective in phytoene synthase. Genetics 168:1249-1257

Meslet-Cladiere L, Vallon O (2011) Novel shuttle markers for nuclear transformation of the green alga Chlamydomonas reinhardtii. Eukaryot Cell 10:1670-1678

Michelet L, Lefebvre-Legendre L, Burr SE, Rochaix JD, Goldschmidt-Clermont M (2011) Enhanced chloroplast transgene expression in a nuclear mutant of Chlamydomonas. Plant Biotechnol J 9:565-574

Minko I, Holloway SP, Nikaido S, Carter M, Odom OW, Johnson CH, Herrin DL (1999) Renilla luciferase as a vital reporter for chloroplast gene expression in Chlamydomonas. Mol Gen Genet 262:421-425

Nelson JAE, Savereide PB, Lefebvre PA (1994) The Cry1 gene in Chlamydomonas reinhardtii: Structure and use as a dominant selectable marker for nuclear transformation. Mol Cell Biol 14:4011-4019

Neupert J, Karcher D, Bock R (2009) Generation of Chlamydomonas strains that efficiently express nuclear transgenes. Plant J 57:1140-1150

Newman SM, Boynton JE, Gillham NW, Randolph-Anderson BL, Johnson AM, Harris EH (1990) Transformation of chloroplast ribosomal RNA genes in Chlamydomonas: molecular and genetic characterization of integration events. Genetics 126:875-888

Nickelsen J, van Dillewijn J, Rahire M, Rochaix JD (1994) Determinants for stability of the chloroplast psbD RNA are located within its short leader region in Chlamydomonas reinhardtii. Embo J 13:3182-3191

Ohresser M, Matagne RF, Loppes R (1997) Expression of the arylsulphatase reporter gene under the control of the nit1 promoter in Chlamydomonas reinhardtii. Curr Genet 31:264-271

Pape M, Lambertz C, Happe T, Hemschemeier A (2012) Differential expression of the Chlamydomonas [FeFe]hydrogenase-encoding HYDA1 gene is regulated by the COPPER RESPONSE REGULATOR1. Plant Physiol 159:1700-1712

Park S, Lee Y, Lee JH, Jin E (2013) Expression of the high light-inducible Dunaliella LIP promoter in Chlamydomonas reinhardtii. Planta 238:1147-1156

Przibilla E, Heiss S, Johanningmeier U, Trebst A (1991) Site-specific mutagenesis of the D1 subunit of photosystem II in wild-type Chlamydomonas. Plant Cell 3:169-174

Quinn JM, Kropat J, Merchant S (2003) Copper response element and Crr1-dependent Ni2+-responsive promoter for induced, reversible gene expression in Chlamydomonas reinhardtii. Eukaryot Cell 2:9951002

Randolph-Anderson BL, Sato R, Johnson AM, Harris EH, Hauser CR, Oeda K, Ishige F, Nishio S, Gillham NW, Boynton JE (1998) Isolation and characterization of a mutant protoporphyrinogen oxidase gene from Chlamydomonas reinhardtii conferring resistance to porphyric herbicides. Plant Mol Biol 38:839-859 
Rasala BA, Barrera DJ, Ng J, Plucinak TM, Rosenberg JN, Weeks DP, Oyler GA, Peterson TC, Haerizadeh F, Mayfield SP (2013) Expanding the spectral palette of fluorescent proteins for the green microalga Chlamydomonas reinhardtii. Plant J 74:545-556

Rasala BA, Lee PA, Shen ZX, Briggs SP, Mendez M, Mayfield SP (2012) Robust expression and secretion of Xylanase 1 in Chlamydomonas reinhardtii by fusion to a selection gene and processing with the FMDV 2A peptide. Plos One. doi: 10.1371/journal.pone.0043349

Rasala BA, Muto M, Sullivan J, Mayfield SP (2011) Improved heterologous protein expression in the chloroplast of Chlamydomonas reinhardtii through promoter and 5 ' untranslated region optimization. Plant Biotechnol J 9:674-683

Redding K, MacMillan F, Leibl W, Brettel K, Hanley J, Rutherford AW, Breton J, Rochaix JD (1998) A systematic survey of conserved histidines in the core subunits of Photosystem I by site-directed mutagenesis reveals the likely axial ligands of P-700. Embo J 17:50-60

Remacle C, Cline S, Boutaffala L, Gabilly S, Larosa V, Barbieri MR, Coosemans N, Hamel PP (2009) The ARG9 gene encodes the plastid-resident $\mathrm{N}$-acetyl ornithine aminotransferase in the green alga Chlamydomonas reinhardtii. Eukaryot Cell 8:1460-1463

Ruecker O, Zillner K, Groebner-Ferreira R, Heitzer M (2008) Gaussia-luciferase as a sensitive reporter gene for monitoring promoter activity in the nucleus of the green alga Chlamydomonas reinhardtii. Mol Genet Genomics 280:153-162

Sakamoto W, Kindle KL, Stern DB (1993) In vivo analysis of Chlamydomonas chloroplast petD gene expression using stable transformation of beta-glucuronidase translational fusions. Proc Natl Acad Sci U S A 90:497-501

Sawyer AL, Hankamer BD, Ross IL (2015) Sulphur responsiveness of the Chlamydomonas reinhardtii LHCBM9 promoter. Planta. doi: 10.1007/s00425-015-2249-9

Schnell RA, Lefebvre PA (1993) Isolation of the Chlamydomonas regulatory gene NIT2 by transposon tagging. Genetics 134:737-747

Schroda M, Blocker D, Beck CF (2000) The HSP70A promoter as a tool for the improved expression of transgenes in Chlamydomonas. Plant J 21:121-131

Shao N, Bock R (2008) A codon-optimized luciferase from Gaussia princeps facilitates the in vivo monitoring of gene expression in the model alga Chlamydomonas reinhardtii. Curr Genet 53:381-388

Sizova I, Fuhrmann M, Hegemann P (2001) A Streptomyces rimosus aphVIII gene coding for a new type phosphotransferase provides stable antibiotic resistance to Chlamydomonas reinhardtii. Gene 277:221229

Sizova IA, Lapina TV, Frolova ON, Alexandrova NN, Akopiants KE, Danilenko VN (1996) Stable nuclear transformation of Chlamydomonas reinhardtii with a Streptomyces rimosus gene as the selective marker. Gene 181:13-18

Smart EJ, Selman BR (1993) Complementation of a Chlamydomonas reinhardtii mutant defective in the nuclear gene encoding the chloroplast coupling factor 1 (CF1) gamma-subunit (atpC). J Bioenerg Biomembr 25:275-284

Specht EA, Nour-Eldin HH, Hoang KT, Mayfield SP (2014) An improved ARS2-derived nuclear reporter enhances the efficiency and ease of genetic engineering in Chlamydomonas. Biotechnol J. doi: 10.1002/biot.201400172

Stevens DR, Rochaix JD, Purton S (1996) The bacterial phleomycin resistance gene ble as a dominant selectable marker in Chlamydomonas. Mol Gen Genet 251:23-30

Strenkert D, Schmollinger S, Schroda M (2013) Heat shock factor 1 counteracts epigenetic silencing of nuclear transgenes in Chlamydomonas reinhardtii. Nucleic Acids Res 41:5273-5289

Tang DKH, Qiao SY, Wu M (1995) Insertion mutagenesis of Chlamydomonas reinhardtii by electroporation and heterologous DNA. Biochem Mol Biol Int 36:1025-1035

Voytsekh O, Seitz SB, Iliev D, Mittag M (2008) Both Subunits of the circadian RNA-Binding protein CHLAMY1 can integrate temperature information. Plant Physiol 147:2179-2193

Walker TL, Becker DK, Collet C (2005) Characterisation of the Dunaliella tertiolecta RbcS genes and their promoter activity in Chlamydomonas reinhardtii. Plant Cell Rep 23:727-735

Young REB, Purton S (2014) Cytosine deaminase as a negative selectable marker for the microalgal chloroplast: a strategy for the isolation of nuclear mutations that affect chloroplast gene expression. Plant J 80:915925 